\title{
Rethinking Buddhist Scholastic Communities Through a Socio-Historical Lens
}

\author{
José Ignacio Cabezón*
}

My early work on scholasticism initially focused on the Tibetan tradition, and later on scholasticism as a comparative category. This scholarship was based almost exclusively on the doctrinal writings of scholastics. While valuable in starting a conversation, in the intervening years I have realized that a more diachronic perspective that emphasizes the social and institutional aspects of scholastic communities is needed. This paper considers three moments in the history of Indian (and to a lesser extent Tibetan) monastic communities of learning: when they first came into being, when they were flourishing, and when they started to die out. Stability, writing, and a commitment to confronting rivals, I argue, are conditions without which Buddhist scholastic communities would not have emerged in India. Although much could be said about the character of these communities during their halcyon days, I focus on three practices that are important to scholastic identity in India and Tibet: debate, commentary, and prayer. Finally, I consider some of the internal challenges and external threats that these communities faced in their twilight.

Keywords: scholasticism; India; Tibet; stability; writing; literacy; orality; argumentation; debate; commentary; prayer; ritual; apophaticism; persecution; book burning

I began to think about scholasticism in the mid-1980s. Having just finished a translation of a Tibetan work on Madhyamaka philosophy - Khedrupjé's (Mkhas grub rje, 1385-1438) Great Digest on Emptiness (Stong thun chen mo) - I was contemplating how best to contextualize that work. ${ }^{1}$ Khedrupjé was a monk and a textualist; he had a keen interest in the interpretation of scripture; and he was a committed rationalist and polemicist. What other communities, I asked myself, approached religion in this way? The study of scripture (and more generally of texts), is central to many religions: Hinduism, Judaism, Christianity, Islam, and Confucianism, to name just a few. These traditions (or some branches of them) have also emphasized rationality and argumentation. Did these various movements have enough in common to warrant grouping them together under a single rubric - to justify considering them "types " of some broader category? If so, what would be that genus of which these various traditions were the species, and how would one construe that broader comparative category?

\footnotetext{
* Correspondence details: José Cabezón, Religious Studies, UC Santa Barbara, Santa Barbara, CA 93106-3130 USA; email: jcabezon@ucsb.edu. 
Contemplating these questions, I suggested, first in a monograph ${ }^{2}$ and then more fully in the introduction to an edited volume, ${ }^{3}$ that scholasticism was that genus, and as the starting point for a dialogue, I posited a number of features that I thought scholasticisms might share.

1. A strong sense of tradition. Scholastics self-identify with a lineage - often claimed to be unbroken - descending from the distant past. This is seen as vulnerable, as threatened by rivals and or by a natural process of decay that is endemic to history. Scholasticism's defense and preservation of tradition is the response to these threats. Identification with and privileging of the past makes scholasticism conservative and cautious about change. Of course, scholastic traditions do change and innovate, but they are loath to admit it.

2. A concern with language in general, and with scripture and its exegesis in particular. Ineffabilist and apophatic forms of religion, the »opposite " of scholasticism in some sense, are skeptical about language - about language's ability to express the highest truths. By contrast, scholastics revel in language and consider it to be indispensable to deliverance (however that be conceived). Scholastics produce written texts, memorize them, recite them, write commentaries on them, and argue about their meaning. This is not to say that linguistic/conceptual understanding is always considered an end in itself. Some scholastic traditions have a strong mystical component and maintain that extra-linguistic religious experiences are essential to salvation, but they also maintain that the only way to those experiences is through language - through deep intellectual engagement with texts.

3. Proliferativity. Scholastic traditions are inclusivistic. Rather to include different ideas, literary works, practices - even if this means having to reconcile inconsistencies - than to exclude and thereby risk the loss of something essential. Some scholastic traditions push inclusivism quite far, claiming that even non-religious forms of learning (grammar, medicine, art, etc.) that are not typically a part of religious learning should be studied and mastered. ${ }^{4}$

4. Completeness and compactness of the canon. Scholastics claim that their canon is complete: that nothing essential to the project of salvation has been left out or overlooked. They also claim that the canon is compact - that everything found in the canon has a purpose and that no doctrine or practice is extraneous. ${ }^{5}$

3 Cabezón, Scholasticism.

4 Mahāyāna Buddhism in particular makes a connection between vast study and the attainment of buddhahood. For example, Maitreya's Mahāyānasūtrālamkāra, fol. 15b, states: „Unless he studies the five sciences, even the highest noble being will not obtain omniscience. So strive to do this, both to defeat [the heterodox], to help others, and to become omniscient yourself. "Śāntideva states in his Bodhicaryāvatāra, fol. 14a, "There is nothing that the children of the Conqueror do not study. There is no merit that scholars so trained will not attain. "His commentator Kalyānadeva (eleventh century?) adds that »[bodhisattvas] always study everything... even the afflictions... but not in such a way that it leads to saṃsāra«; Bodhisattvacaryāvatärasaṃskāra, fol. 39a.

5 Longdol Lama (Klong rdol bla ma, 1719-1794), who is known for compiling lists of important doctrinal terms, is quoted in his biography as saying, "[Some may claim] that it is unnecessary to compile a lot of lists of difficult terms of subjects that one has already studied. However, some lamas have said that when, at some future point, one achieves the eighth bodhisattva stage and obtains the ssamādhi of valor`, all of the doctrines that one had previously studied manifest [in one's mind]." The implication is that even if knowledge is lost in the short-term - for example, in the transition from one life to the next - it is recuperated at some future point. Rta tshag, Klong rdol, 44. 
5. A belief in the epistemic accessibility of the world. The universe, scholastics maintain, is orderly and intelligible. Most important, the path to salvation is intellectually accessible to human beings. Scholastics may have different theories of what knowledge is and how it works. Some consider certain aspects of the world - for example, the ultimate - to be inaccessible. But most scholastics have a robust epistemology, and they maintain that the acquisition of knowledge is an important part of the religious path.

6. Systematicity. Scholastics strive to reproduce in their writings the basic orderliness of the world. Their literature often has a complex structure that divides and subdivides the subject matter to ensure (a) a logical flow to the "narrative", and (b) consistency between its different parts. This orderliness is seen as essential to pedagogy.

7. Rationalism. The reasoned elucidation of doctrine and the rational defense of tenets are perhaps the most central attribute of scholasticism. Rational, conceptual understanding may be a stepping-stone to some supra-rational, religious experience, to the ethical transformation of the person, or to both, but reasoned understanding is considered an important aspect of the religious life.

8. Self-reflexivity, the critical analysis of first-order practices. Scholastics not only engage in exegesis or commentary, but also in second-order reflection on hermeneutics. They comment on texts, but they also reflect on why commentary is necessary, how one should go about it, etc. They not only engage in rational argumentation, but also theorize about what constitutes a rational argument, the conditions that make inference valid or invalid, and so on.

This list - crafted almost thirty years ago - derived chiefly from my work on Indian and Tibetan Buddhism. I offered it as a starting point for a broader conversation and invited scholars of other religions to consider whether or not these features were found in the traditions they studied. I did not expect that all of these attributes would be found in every tradition, but if scholasticism was a viable cross-cultural "genus", then I expected that the various "species" - Christian, Islamic, Confucian, etc. - would be related in a complex way. Buddhist and Islamic scholasticism might have some features in common, but these might not be the same ones that Islamic scholasticism would share with Confucian scholasticism, and so on. In other words, I expected that the generic category scholasticism would cohere through the relational patterns that Wittgenstein called "family resemblances«. As different historical traditions were considered, I thought, they would suggest to us other attributes not present in my list, and some of the ones that I initially thought to be central, I realized, might instead be only peripheral. As Ernest Gellner states, "we can never be sure that data that come our way in the future will still fit into the generalization set up on the basis of past data. ${ }^{6}$ As other, non-Buddhist examples were considered, I expected that certain features would emerge as more central than others, but I never expected that we would find an essence to scholasticism, a single set of features that all scholastic traditions would share. I will not say any more about that earlier work except that it was an interesting exercise in comparative, cross-cultural analysis. ${ }^{7}$

6 Gellner, Concepts and community, 167-186.

7 The similarities and differences between the various traditions considered - medieval Latin, Islamic, Judaic, Taoist, and Neo-Confucian - are discussed in the conclusion to my edited book Scholasticism. 


\section{Moving Forward}

Since those early reflections on scholasticism I have thought about these issues many times, most recently while writing a book on Sera Monastery, ${ }^{8}$ one of Tibet's premier monastic academies and an example of a scholastic community if there ever was one. As I started to write my book on Sera, I realized that to truly understand such an institution one first needed to understand the Indian background, the evolution of monasticism and scholasticism in India. While my earlier work on scholasticism was not irrelevant to this, I also realized that it was synchronic - a snapshot of one form of scholasticism, chiefly Tibetan Geluk (Dge lugs) during one period of Tibetan history (fifteenth to seventeenth century). It did not explore the Indian antecedents of Tibetan scholasticism, the conditions that made Indian scholasticism possible in the first place, how elite scholarly communities had evolved on the subcontinent, or the way they changed under different historical, economic, and political conditions. Synchronic and structuralist approaches are valuable, but they are not sufficiently rich to fully understand a religious phenomenon. They need to be complemented with more diachronic, functionalist, and sociological approaches. This is what I propose to do in this paper. Focusing chiefly on India, but with occasional references to Tibet, I offer here a more historical and dynamic approach to scholasticism.

The discussion has three parts. The first explores the conditions necessary for the emergence of scholarly communities in India. Buddhism did not develop a scholastic tradition until the first centuries of the Common Era. Why did it take 500 years for this to occur? What conditions facilitated this shift? The second section deals with three key features of Indo-Tibetan scholastic communities: memorization, debate, and religious practice (including ritual, prayer, merit-making, and meditation). Each of these are mammoth topics in their own right, so I focus in each case on an aspect that has become central to my thinking on these matters over the past decades. The third and final portion of the paper examines two challenges to Buddhist scholasticism, one intellectual or ideological, and the other political-economic.

\section{Part I: Conditions for the Possibility of Scholasticism}

Is it a foregone conclusion that Buddhism would have developed a culture of specialized learning - that it would become scholastic? The Buddha of the canonical "sermons" - of the Nikāyas and Āgamas - is often critical of metaphysical speculation and fixed doctrinal viewpoints. In the Cula Malunkya Sutta (Majjhima Nikāya 26), ${ }^{9}$ he is asked a series of questions about the origins and end of the world, the relationship of body and self, and what happens to a buddha after he dies. He responds with the famous parable of the arrow. Would a man who has been struck by a poisoned arrow refuse treatment until he is given complete information about the archer who shot him and the details of the bow, arrow, and poison he used? Surely not; he would insist on being treated immediately. Likewise, the Buddha says,

9 Cula Malunkya Sutta, 26; see also the Aggi Vacchagotta Sutta, a critique of fixed positions, and the Sabbasava Sutta, where such positions are called "a wilderness of views«. 
he offers a therapy for suffering, not speculation that is "unconnected to the goal, not fundamental to the holy life.$^{10}{ }^{10}$ This response suggests a certain skepticism about doctrinal speculation that lacks direct salvific utility. And yet the Buddha himself often engaged opponents in philosophical arguments. ${ }^{11}$ And the monks' ordination ritual - an early text - concludes by stressing the importance of study.

From this day forward, you should receive instructions on the scriptures (ágama, lung); you should recite them [for others] (klag pa) and rehearse them [for yourself] (kha ston byed $p a$ ). You should master the [teachings of] the aggregates; master the elements; master the sense bases; master dependent arising; master what is right and wrong... You should not give up striving to achieve these ends. ${ }^{12}$

The Vinaya therefore enjoins monks to study and to gain an understanding of Buddhist doctrine. In the end, Buddhist scholarly communities did emerge in India, but if this was not a foregone conclusion, then what conditions made the scholastic project possible? Three come to mind: the shift from a peripatetic to a sedentary lifestyle, the emergence of writing, and intellectual exchanges with competing schools of thought.

\section{Stability}

Like other ancient South Asian ascetic orders, the early Buddhist monastic community was itinerant. ${ }^{13}$ The Buddha himself traveled extensively, and he urged his monks to follow his example and take to the road "in every direction" so as to preach "for the good of the many, out of compassion for the world«. In their travels, monks would spend the night in parks and groves, under trees, in caves, empty buildings, and, when so invited, in people's houses. Other mendicant sects remained sedentary for the three or four months of the rainy season. But wandering was so central to early Buddhist asceticism that monks initially traveled even during the rains. This led to criticism, as mendicants of other sects denounced Buddhist monks to the laity as uncaring about the insects - more common during the rains - that they might trample underfoot. »Friends, these monks, the sons of Śäkya, kill; they have not renounced

10 For an analysis of why certain questions are left unanswered or unexplained by the Buddha of the Lankāvatärasūtra, a Mahāyāna work, see Solomon, Indian Dialectics 2, 722-723.

11 See Solomon, Indian Dialectics 2, 678, for references to some of the Buddha's more important conversations with rivals and his method of argumentation. See also Manné, Dīgha Nikāya debates, 117-136.

12 Vinayavastu, 1 , fol. $87 \mathrm{~b}$.

13 There are some exceptions to the rule that monks must wander. Monks who were too old were exempted, as were novices and new monks who were still being trained. But in the Mūlasarvāstivāda Vinaya (Vinayavastu, 1, fols. 99a-b), the Buddha tells monks who had been ordained for at least five years and who knew the monks' rules that they had to leave their teachers and wander (gnas par mi bya'i ljong rgyur bya ste) after the rains retreat. 
killing ... They trample upon many hosts of insects and microorganisms and deprive them of life. $\aleph^{14}$ The Buddha then relented and permitted his monks and nuns to also observe the varșa (Tib. g.yar gnas), the "rainy season retreat «. The first rains retreat brought together monks who were not used to living in community and rules had to be instituted to socialize them into a communal life. ${ }^{15}$

Shortly after the Buddha's enlightenment, the Magadhan king Bimbisāra offered him a garden or park (äräma) ${ }^{16}$ called Veluvana, the "Bamboo Grove«. Other similar gifts - the Jetavana, offered by the wealthy banker Anathapindada, etc. - followed. Structures were built at these sites, but they were only temporary dwellings, and early monks continued to wander even after patrons had built viharras, the first rudimentary monasteries. ${ }^{17}$ That said, the adoption of the rains retreat appears to be a turning point in the history of the order, beginning a slow transition from itinerancy to the sedentary life that would characterize later Buddhist monasticism. ${ }^{18}$

We do not know precisely when the Buddhist sangha became sedentary or cenobitic when it made the transition from a wandering to a communal way of life - and this probably happened in different places at different times, but archeological evidence suggests that it was before the second century BCE. ${ }^{19}$ This kind of stability, I believe, is a prerequisite to the emergence of Buddhist scholastic communities, for it is hard to imagine that a loosely knit and peripatetic group of monks could have given rise to a culture of deep learning and intellectual specialization. Wandering monks had less leisure: less time to study, to teach, and to write. And the material artefacts that scholars required, especially physical books, could not, of course, be easily transported from one place to another. Non-Buddhist Indian traditions of learning often survived in familial lineages without bonds to formal institutions like monasteries. But this was hardly possible in ascetic traditions like Buddhism in which religious specialists renounced the family life. Lay scholars were exceedingly rare in Buddhist India, and it is not surprising that some of them - like Candragomin (fl. sixth century CE) - ended up living in monasteries, the most natural home of Buddhist scholars.

15 This is reflected in the texts, which show a great deal of concern with monks' behavior - especially their speech - during this time. For instance, monks were advised, at the beginning of the retreat, not to engage in idle gossip, but not to go so far as to keep total silence. In the interest of communal harmony, monks were also not allowed, for the duration of the retreat, to point out each other's faults - something that the Vinaya otherwise compelled them to do.

16 On the relationship of the Buddhist vihära or äräma to the Indian garden, see, Schopen, Buddhist Nuns, chap. 11.

17 The Vinaya itself suggests that itinerancy continued to be the norm. For example, in the Mūlasarvāstivāda Vinaya$v a s t u$, the Buddha requires monks to start wandering immediately upon the end of the rains retreat - going a substantial distance from the site as soon as the retreat was over so that they would not grow attached to the place.

18 P. V. Bapat noted long ago that the Pāli Vinaya (Mahāvagga 15.4) also suggests that monks spent time during the rains retreat - or at least during its closing ceremonies, the Pavāraṇā - teaching and discussing doctrine, which may be one of the first acts of Buddhist intra-communal teaching and learning. He further suggests, intriguingly, that the expression dhammakathika found in that passage refers to doctrinal specialists who engaged in debate (kathā). Bapat, 2500 Years of Buddhism, 179-180,

19 See Shaw, Buddhist monasteries. 
In Tibet too monasticism was central to both the emergence and the preservation of specialized learning. Buddhist texts were first translated into Tibetan in monasteries beginning in the ninth century with the patronage of the Tibetan royal court. When, after a hiatus of two centuries, scholarly learning was revived in Tibet, this took two distinct paths: the translation and transmission of Indian texts (1) through lay translators who traveled to India and passed on their newly acquired (mostly Tantric) knowledge privately to small groups, often privileging members of their own family or clan; and (2) through court-sponsored monk-scholars who trained in India and then returned to Tibet to found monasteries, passing on their (mostly exoteric) knowledge to other monks. The lay Tantric translators - individuals like Drogmi ('Brog mi shākya ye shes, 992-1043), Marpa (Mar pa chos kyi blo gros, 1002-1097), Gö ('Gos khug pa lhas btsas, eleventh century), Ra (Rwa lo rdo rje grags, 10161128), etc. - transmitted their esoteric teachings to select disciples, often charging vast sums, in part to pay off the debt they had incurred from their trips to India. Monk scholars did not have such debt because they were being sponsored by patrons like the kings of Ngari in western Tibet. Because monks were unencumbered with familial obligations and concerns over patrimony, and because their teachings were also (mostly) of an exoteric sort, they were more free, transmitting their knowledge publically to other monks. Not only were monks more open-handed, the teachings themselves were "safer" in monasteries. Tibetan history shows us that when it comes to the preservation of a tradition, patrilineal descent is not as effective as monasticism. Too much can go wrong - the failure to produce progeny, infighting within the family, unqualified or uninterested heirs - to make hereditary transmission very effective. There are, of course, exceptions, but as a rule, only those Tibetan religious lineages that made their way into monasteries were preserved for posterity. ${ }^{20}$ In any case, the model of private instruction was eventually eclipsed by the public pedagogy that was available in monasteries. By the end of the twelfth century, it was no longer necessary for Tibetans to travel to India to study Buddhism or to pay large sums for instruction; they could simply enter one of a number of Tibetan monasteries and get a first-rate Buddhist education for free. In Tibet as in India, communal monasticism was the social structure most conducive to the emergence and preservation of Buddhist learning.

20 Take, for example, the tradition called Severance or Chö (Chod), first expounded by the female saint Machig Labdrön (Ma cig lab sgron, 1055-1149). Chö as a distinct school died out, but its key practices survived because they were preserved by monks and nuns, who have been the custodians of these teachings for a millennium. Likewise, Drogmi's Path and Effect (Lam 'bras) instructions almost died out during the period, early in their history, when they were transmitted privately. They survived because of the decision of the Tibetan scholar Sachen (Sa chen kun dga' snying po, 1092-1158) to make them more public, and they only flourished when they began to be taught and practiced in monasteries like Sakya. 


\section{The Transition from Orality to Literacy}

Shortly after the Buddha's death, the elder Mahākāśyapa is said to have convened a council of 500 monks at Rajjagṛha, the capital of the Magadhan kingdom, and had them recite everything that they could remember of what the Buddha had taught. ${ }^{21}$ Different portions of the Buddha's teachings were then assigned to different monks, who memorized them (or some version of them) and became responsible for orally transmitting them to their disciples. This oral tradition continued even after the teachings began to be written down shortly before the turn of the Common Era.

Passages suggesting how new monks were trained by their teachers are found scattered throughout the Buddhist canon. In the Vinayavastu, for example, two newly ordained monks are set to memorizing a portion of the Buddhist canon, the Ekottarikāgama collection, »And making great effort, they were able to recite it, which caused those monks' teacher to rejoice. $\aleph^{22}$ The same text mentions the proper way of receiving the transmission of scriptures (lung nod pa): with one's eyes open, facing the teacher, and sitting close to him. ${ }^{23}$ One of the inscriptions of the Mauryan king Aśoka (Minor Rock Edict no. 3) suggests that in the third century BCE monks were still transmitting the scriptures only in an oral fashion, for after mentioning a number of different sermons of the Buddha, the edict is silent about any physical texts and instead urges monks and nuns to »constantly listen to and remember« them.

21 The account is found in the Mūlasarvāstivāda Kșudrakavastu, 2, fol. 473b. See also Skilling, Redaction, recitation, and writing, 55-60, for discussions of the councils in other works, and Allon, Oral composition and transmission.

22 See, for example, Vinayavastu, 1, fol. 134b.

23 Ibid., fol. 144b. 
Monks and nuns may have started to memorize and recite scriptural material even during the Buddha's own lifetime, ${ }^{24}$ but it is really after his death - when the preservation of the teachings hinges on memorization - that this activity becomes so central to the tradition. The Vinayavibhanga implies that there was a division of labor in the sangha. In one story, a newly ordained monk is told by his teacher that "the work of monks is of two kinds: meditation and recitation $(k \log p a)$. « The young monk is given a choice of which path to take. He chooses to be a reciter. But his teacher is a meditator, so he sends the boy to another elder to learn the scriptures, which the young man masters in due time. ${ }^{25}$ In another case, a novice is asked to make a choice between the two options and he chooses both. As a result, he trains as a reciter in the summers and as a meditator during the winters, perfects both skills, and becomes an arhat. ${ }^{26}$ The Vinaya mentions great feats of memorization - instances of monks and nuns ${ }^{27}$ memorizing one of the four large collections of sermons, called the Ägamas, in its entirety, or even the entire canon, the Tripitaka. Even the laity, to a limited extent, memorized scripture. ${ }^{28}$ The scriptures were not only supposed to be memorized and recited, they were also supposed to be understood and contemplated. The Mūlasarvāstivāda Vinaya speaks of four or five stages in the acquisition of scriptural knowledge: receiving the text orally from the teacher (lung 'bogs pa), memorizing it (dran par byed pa), reciting it (kha ston byed pa), familiarizing oneself with the content ('dri bar byed pa), and contemplating it (yid la byed pa).

Although memorization and study were clearly valued, the Vinaya also exhibits a certain ambivalence about learning. Words were seen as dangerous things. Like a snake, they can "bite", causing harm to those who do not know how to handle them properly. ${ }^{29}$ Monks are censured when they simply recite what they have memorized without thinking about what the words mean. ${ }^{30}$ They are criticized for studying the scriptures just to defeat opponents

24 Anālayo, Dìrgha-ägama Studies, 488-499. The discussion revolves around the Sañgìti Sutta, Dīgha Nikāya 33. There, Sāriputta leads the monks in a joint recitation (sañgiti) so that the Buddhist sangha might avoid the infighting that had befallen a rival monastic group. This suggests not only that monks performed recitations during the Buddha's own lifetime, but that the communal recitation of the Buddha's teachings was seen as having the social function of unifying the monastic community. See also Skilling, Redaction, recitation, and writing, 54. In a fascinating passage in the Mūlasarvāstivādavinaya's Kșudrakavastu (1, fols. 67n-68a), the lay devotee Anāthapiṇḍada hears non-Buddhists reciting their scriptures and thinks to himself, "Their religion may be wrong, but they recite their texts in a sonorous deep voice, whereas when our noble monks recite the texts, it sounds like a pile of juniper berries crackling underfoot." He therefore goes to the Buddha, shares his thoughts, and from then on Buddhist monks too recite in sonorous, deep voices.

25 Vinayavibhanga, 1, fol. $181 \mathrm{~b}$.

26 Vinayavibhainga, 1, fols. 375a-b; and 3, fol. 94b.

27 Nuns who had mastered the Tripițaka are mentioned in the Vinayavibhanga, 3, fols. 156a and 336a; and several times in the Bhikșunivinayavibhanga, fol. 249b-250b, 387b, etc., including the case of a young girl who is an expert reciter of scripture (fols. 253a-b). See also Anālayo, Dïrgha-āgama Studies, 497.

28 See, for example, Vinayavibhainga, 1, fol. 241a, where a Brahmin asks a monk whether lay people are allowed to memorize the three baskets. The monk replies that they are allowed to memorize two of them - the Sutras and the Abhidharma - but not the Vinaya.

29 For the canonical references to this analogy - that words are like a snake - see Anālayo, Dïrgha-āgama Studies, 467 n. 62. Monks are not only warned of the dangers of words in general, but in the Pāli tradition also of specific genres of literature, most notably poetry, on which see Upali Sramon, Elements, 19-39.

30 Anālayo, Dïrgha-ägama Studies, 468, 470-471. 
in debate. ${ }^{31}$ They are scolded for being stingy and not sharing with others what they have learned..$^{32}$ Erudite monks who are arrogant are also severely criticized. ${ }^{33}$ In sum, the study of the scripture is viewed as being filled with snares, and being a master of the Tripitaka was not seen as a guarantee of holiness. But when pursued correctly - when a monk understood both the words and the meaning of the scriptures, when he used his learning to liberative ends, freely shared it with others, and remained humble - both learning and the learned are extolled.

The Mūlasarvāstivāda Vinaya contains different layers that belong to different periods. When it mentions the scriptures or the Tripitaka, it is mostly referring to these collections as orally transmitted texts. Had Indian Buddhism remained a strictly oral tradition, it is unlikely that we would have seen the rise of scholasticism. How, after all, would one go about composing a commentary without writing? And even if that were possible, how would such a text be preserved? There is no record (as far as I know) of commentaries or treatises - the principal "medium « of Buddhist scholasticism - being composed or transmitted in a strictly oral format. Put more simply, Buddhist scholasticism would not have been possible without writing.

Per the testament of Nearchus, an officer in Alexander's army, writing was being used in the Indus river basin in the fourth century BCE, but Megasthenes states that writing did not exist in Magadha around 300 BCE. ${ }^{34}$ This suggests that writing spread from west to east. Writing grew in popularity from the reign of Aśoka in the mid third century BCE. When the Vinaya makes reference to the scriptures, as we have noted, it mostly assumes that these are oral texts. But some passages in the Vinaya, which perhaps date to a later period, refer to writing and books. ${ }^{35}$ The Vinayavastu, for example, speaks of a boy who learned writing (yi ge 'bru ba, sic.), reading (bklag pa), and poetry (snyan dngags bya ba). ${ }^{36}$ When the same work discusses how the community ought to dispose of the property of a deceased monk, it states that a portion should go "to the Dharma", which it glosses as "the writing of the Buddha's word«, i.e., to funding written texts. ${ }^{37}$ It also speaks about the disposition of a deceased

31 Anālayo, Dìrgha-ägama Studies, 467. Although argumentation and debate would become an important part of monastic learning in later times, during the early period it is often condemned. See Solomon, Indian Dialectics 2, 683-686. And yet, as Manné (Dïgha Nikāya debates) has shown, over half of the suttas in the Dïgha Nikaya have the Buddha debating various opponents.

32 The Vinayavastu, 2, fol. 505a-b, tells the tale of such a monk in verse. "In my past life, I was a learned ascetic, a holder of the Tripitaka, but I was stingy with the Dharma. I would not recite or explain the Dharma to other monks, thinking that if I did so, they would become as learned as me... " The monk, however, has a change of heart when he is close to death and spends the last week of his life in a teaching marathon to make up for his earlier stinginess. When he dies, he is reborn as a god. See also Vinayavibhanga, 3, 116b-117a. Analayo, Dirgha-ägama, 468, also mentions monks who memorize texts but who do not teach; they are compared to clouds that thunder but give no rain.

33 Vinayavastu, 1, fols. 174b-175a, is a narrative of a monk who had mastered the entire Tripițaka, but who had become arrogant. A similar story - of learning leading to arrogance - is found in ibid., fol. 347a-b.

34 Stoneman, Greek Experience of India, 402-403.

35 See Bronkhorst, Literacy and rationality, 797-831. On various references to writing in Indian Buddhist texts see Skilling, Redaction, recitation, and writing, 61-62. Skilling also discusses Tibetan historians' views that the Tripitaka was first written down at the time of the third council.

36 Vinayavastu, 1, fol. 336a.

37 Vinayavastu, 3, fol. 167a.

medieval worlds $\bullet$ No. $12 \cdot 2020 \cdot 33-67$ 
monks' books. His Buddhist books, it says, are to be kept for the use of the community and placed in the monastery's library ( $m d z o d$ ). His non-Buddhist books are to be sold and the funds distributed to the Sangha..$^{38}$ All of this implies that at the time that these portions of the Vinaya were redacted around the third century CE, monks knew how to read and write, collected Buddhist and non-Buddhist books, and stored those books in libraries.

Unlike the Vinaya, which makes reference to both oral and written traditions, early Mahāyāna literature - for example, the Perfection of Wisdom in 8000 Lines (Aștasāhasrikā Prajñapāramitā), which dates to slightly before the Common Era $^{39}$ - emphasizes writing and books from the outset. The Asța suggests that the Perfection of Wisdom ought to be made into books (pustakagatām krtvā, glegs bam du chud par byas pa) which ought to be preserved (dhärayet, 'chang ba), stored (sthäpayet, bzhag pa), and worshipped in various ways (bahuvidhäbhiś ca püjäbhih ... püjayet, mchod pa rnam pa mang po dag gis mchod par byed pa)..$^{40}$ The copying, reading, worship, explanation, and gift of physical books is also enjoined upon Mahāyānists in later Prajnāpāramitā commentarial literature, specifically in the list of »ten activities in regard to the Dharma ${ }^{41}{ }^{41}$ By the mid second century CE there were enough Buddhist books in circulation that the Parthian scholar An Shigao could translate some 176 different Buddhist works (a million words) into Chinese. ${ }^{42}$ By the third century CE, writing and books were so integral to Buddhism that the Buddha's biography gets rewritten to include an episode, missing in the earlier biographies, in which he goes to school (lipiśälā) and there demonstrates his mastery of writing. The episode also starts to be depicted in Gandharan art in this same period (figures 1 and 2). ${ }^{43}$

38 Ibid. See also Walser, Nägärjuna in Context, 142-147; and Bronkhorst, Literacy and rationality, 27.

39 See Falk and Karashima, First-century Prajñäpāramitā manuscript.

40 Asțasāhasrikā, ed. Vaidya, 32; Shes rab kyi pha rol tu phyin pa rgyad stong pa, 1, fol. 58a. See also De Simini, Of Gods and Books for an overview of recent research on the cult of the book (or »manuscript«) in early Mahāyāna.

41 These are the daśatha dharmacaritam, chos spyod pa rnam pa bcu. The list is found in a verse, quoted by many later authors, in Distinguishing Between Middle and Extremes (Madhyāntavibhäga, fol. 44a), a text attributed to Maitreya and dating to the third or fourth century. Vasubandhu's Commentary, the Madhyāntavibhägabhāsya, fols. 21a-b, glosses each of the ten. The source for the Sanskrit equivalents is the Mahāvyutpatti lexicon (nos. 903-913). See also Negi, Tibetan-Sanskrit Dictionary, 1286.

42 Tajadod, Role of Iranians, 61-62.

43 See Hargreaves, Masterpieces of Oriental art, 131-133; Ali and Qazi, Gandharan Sculptures, 68-70; Ducoeur, Bodhisattva à la salle, 385-424. 


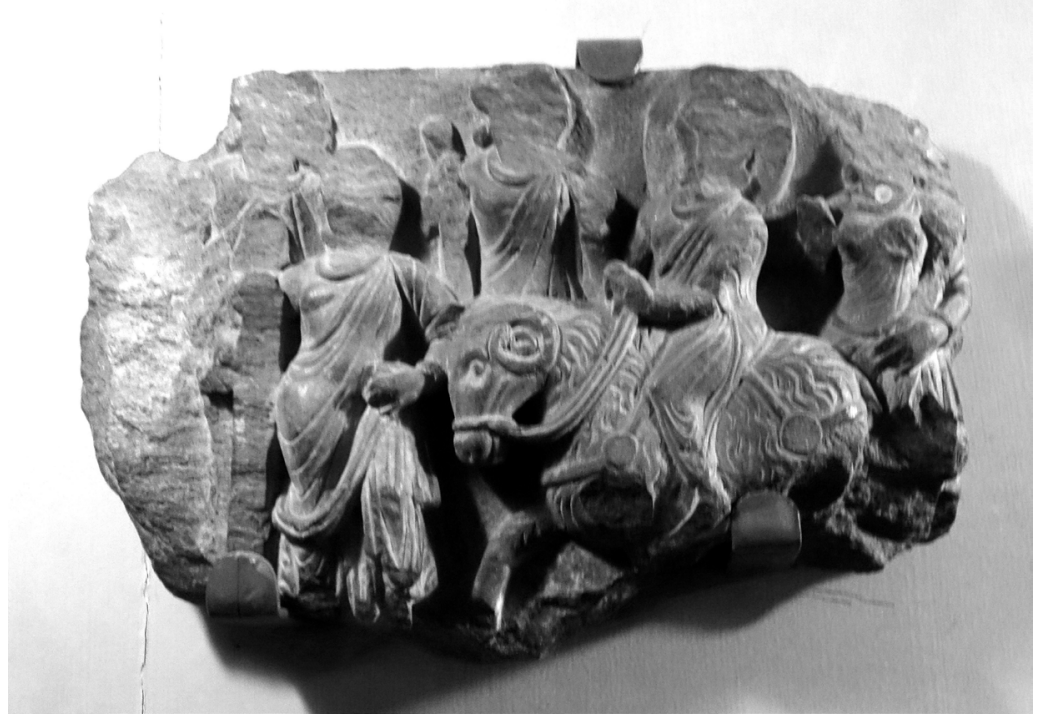

Figure 1: The young Buddha goes to school on a ram. Sahri Bahlol, Pakistan, second to third century CE. Peshawar Museum, access no. 3736. Photo: J. Cabezón.

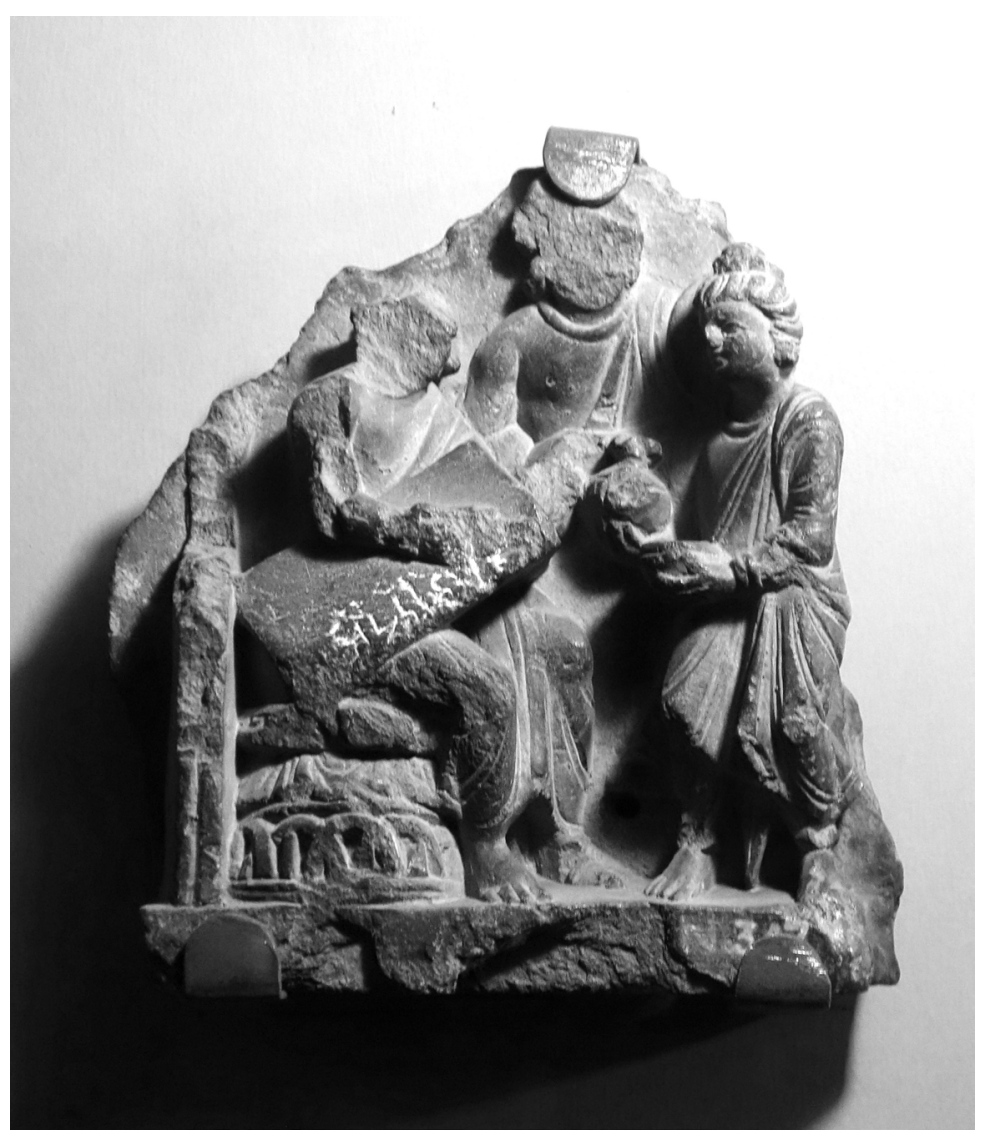

Figure 2: The young Buddha (right) approaches his seated teacher in the classroom to show him his writing tablet. Gandhara, exact provenance unknown. Peshawar Museum, access no. 2737. Photo: J. Cabezón. 
Writing transformed Buddhism. Even if texts can be passed down accurately in a strictly oral fashion (the Vedas are proof of this), oral texts are not as easily commented upon, quoted, summarized, debated, or taught. In the mid twentieth century, a number of European and North American scholars (most notably Eric Havelock, Walter Ong, and Jack Goody) began to explore the cultural and psychological implications of writing. Something quite radical takes place, they claimed, when literacy emerges in a society that had previously transmitted its traditions only orally. Among other things, the written word permits new and more complex forms of knowledge - for example, philosophy. Whatever the truth of these theories - and there have indeed been challenges - writing clearly changed the face of the Buddhist tradition. Economically, writing introduced new patterns of patronage, since the production of written texts required investment in raw materials (ink, birch bark or palm leaves, etc.) as well as human labor (scribes). ${ }^{44}$ Writing also made it possible, or at least easier, for monks to begin authoring commentaries and independent treatises (śästras). ${ }^{45}$ The śästra genre, and especially the versified synoptic form that allowed monks to summarize and organize large quantities of scriptural material, made the canon more accessible, especially to students. The scholastic texts par excellence, śástras are highly intertextual, constantly quoting or borrowing from other works. It is hard to imagine that Buddhist monks could have composed such complex works in the absence of writing. And just as writing was essential to the composition of śästras, it was also essential to teaching them - that is, to scholastic pedagogy. This is not to say that writing replaced the oral dimension of Buddhist learning, for we know that monks continued to memorize and transmit the scriptures orally for centuries after writing was introduced. Although the study of first-order scripture is never abandoned, therefore, over time the second-order śástras partly displaced scripture as the focus of scholarly attention and pedagogy. ${ }^{46}$ Tibetans went even further, practically abandoning the study of scripture and constructing their curricula around the study of śāstric works.

44 On the new economies of patronage that writing inaugurated, see Walser, Nāgārjuna in Context.

45 Rules for composing exegetical works were set forth by Vasubandhu in his Science of Exegesis (Vyākhyāyukti). On this work, see Cabezón, Vasubandhu's Vyākhyāyukti; Nance, Speaking for Buddhas; and Schoening, Sūtra commentaries.

46 The Tibetan historian Tāranātha (1575-1634) states that before the seventh century Indian Buddhist monks »focused chiefly on explaining the Mahāyāna sūtras and explained the śāstras as an ancillary enterprise. But after that, the situation was reversed. With the exception of the Prajñāpāramitā, study focused on the treatises, and it was these texts [i.e. the śāstras] that were disseminated. "Tāranātha, Rgya gar chos 'byung, 208. For a list of the most important Buddhist śästras - both exoteric and esoteric - in eleventh-century India, see the final pages of Atiśa's Ratnakarạ̣dodghata nāma madhyamakopadeśa, fols. 112b-116b. 


\section{Exchanges with Rival Schools}

Neither stability nor writing was enough to bring about Buddhist scholasticism. One other condition was necessary. The seventh-century Buddhist logician Dharmakirti famously claimed that we understand words and concepts by understanding what they are not. If this is true at all, then it is as true of communities as it is of quotidian things. Similar ideas - that identity or self-consciousness emerges in conversation or dialogue with »the other " - are found in the work of a variety of thinkers from William James to Michael Bakhtin. ${ }^{47}$ Scholastic communities too came to understand who they were by understanding who they were not, by distinguishing themselves from rivals by studying their works and by arguing against them.

Rational argumentation in India is very old, certainly predating Buddhism..$^{48}$ Accounts of arguments and debates are found in the oldest Upanișads. The Buddhist sütras also portray the Buddha as debating with different interlocutors, ${ }^{49}$ and there are miscellaneous references in non-Buddhist works to debates between Buddhist monks and followers of other traditions - some during the Buddha's own lifetime.$^{50}$ Early Buddhist attitudes to rational inquiry, debate, and argumentation ( $v \bar{a} d a$ ) are ambivalent. ${ }^{51}$ On the one hand, it is considered the duty of monks to defend their faith against heterodox rivals. On the other hand, the Buddha advises his disciples to avoid "fruitless debates.$^{52}$ After the Buddha's death, monks seem to have focused most of their polemical energy internally against other Buddhist sects. The stories of early Buddhist schisms, and texts like the Kathāvatthu and Mahāvibhāșā, describe various intra-Buddhist controversies, yet hardly mention debates with non-Buddhists. But early sources also state that well-trained monks were required not only »to explain their own teacher's doctrine, teach it, proclaim it, establish it, disclose it, analyze it, and elucidate it,« but also to "refute thoroughly with reasons the prevalent tenets of others «. ${ }^{53}$

47 See, for instance, Săftoiu, Constructing and negotiating identity.

48 See Matilal, Logic, Language and Reality, 9; and Solomon, Indian Dialectics.

49 Manné, Dīgha Nikāya debates.

50 See, for instance, Bollee, Adda. The debate has to do with the issue of whether, as regards the accrual of karma, it is the act itself or its intention that is more important.

51 See, for instance, the passages from the Pãli canon quoted by Xing, Rational argumentation, 184-185. In the first passage, the Buddha distinguishes his way of teaching, which is based on direct experience, from that of "reasoners and investigators". In the second, the Buddha ranks logic, inference, and reasoning as unsatisfactory ways of gaining knowledge.

52 On the Buddha's skepticism about argumentation, see the previous note and the references in Cabezón, Buddhist narratives, 73 n. 4.

53 Cited in Bodhi, Buddha's Teachings, 72. On the various sources of this passage, see ibid., 202 n. 2. 
When Brahmanical thinkers (especially the followers of Nyāya school) began to critique the fundamental doctrines of Buddhism - momentariness, the non-existence of the soul, etc. - Buddhists begin to respond. For example, Nāgārjuna (second century CE) argues against key Nyāya tenets - the existence of a soul, their typology of incontrovertible knowledge (pramāna), and so on. Johannes Bronkhorst, however, credits not Mahāyānists like Nāgārjuna, but the Hīnayāna Sarvāstivādins with being the first real Buddhist philosophers and suggests that their disputes with Brahmanical opponents predate Nāgārjuna. ${ }^{54}$ Whatever the case, writing had a huge impact on inter-religious exchanges. As Bronkhorst notes, „Writing can help in composing particularly complex works... [but] it can have other effects too. It allows readers access to works that do not belong to their own tradition. ${ }^{55}$ Not only did writing give Buddhist monks access to Brahmanical literature, it also allowed them to study the literature of rival Buddhist schools. ${ }^{56}$ And, of course, it provided monks with a new and more permanent medium in which to respond to their opponents, both Buddhist and non-Buddhist. The Vinaya, as already noted, makes it clear that Buddhist monks studied the works of their rivals, which it apparently finds disturbing enough that it attempts to regulate it. For example, the Vinaya's Kșudrakavastu states that only mature monks who know how to refute opponents' positions should be allowed to study heterodox treatises (śästras) and that young monks should not be given access to such works. Even elder monks, the text continues, should only spend a third of their time studying heterodox works and should recite them ('don) only at night, probably so that others could not hear them. ${ }^{57}$ That monks were reciting their opponents' works means, of course, that they were memorizing them. The fact that the Kssudrakavastu does not forbid this activity altogether suggests that Buddhist monks of this period had already begun to engage their non-Buddhist peers in serious intellectual exchanges and needed to be trained for these encounters. The Chinese pilgrim Xuanzang (600-662) informs us that classes in the tenets of the heterodox schools were taught at Nālandā. ${ }^{8}$ The Kșudrakavastu suggests that Buddhist monks' training in Brahmanical philosophy had started several centuries before Xuanzang.

54 Bronkhorst, Literacy and rationality, 18-26. Bronkhorst believes that the Sarvāstivāda Abhidharma is more philosophically coherent (and its Theravāda counterpart comparatively less so) because the Sarvāstivādins were actively engaged in conversation with - and were forced to refine their positions in light of the attacks of - non-Buddhist challengers. It strikes us, however, as implausible to claim, as Bronkhorst does, that Sarvāstivādins were the first to maintain a tradition of debate in India.

55 Bronkhorst, Literacy and rationality, 16.

56 There is a famous story that Vasubandhu absconded from Kashmir carrying the Sarvāstivāda texts, with Kashmiri monks in hot pursuit. Vasubandhu's Kośa was written, at least in part, as a critique of those Sarvāstivāda teachings. Whatever the truth of the tale of Vasubandhu's flight from Kashmir, it bespeaks the fact that in a new era where writing gave opponents access to the views of one's own school, monks wished to safeguard their written texts precisely so that they would not become fodder for others' critiques.

57 Vinaya Kșudrakavastu, 2, fol. 106b. Exchanges between Buddhists and non-Buddhists on a variety of topics are also mentioned in the Spitzer Manuscript, on which see Franco, Spitzer Manuscript. Of course, Aśvaghoṣa (and to a lesser extent Nāgärjuna, his slightly later contemporary) were already critiquing the views of Brahmanical thinkers a century or more before either the Vinaya or the Spitzer manuscript.

58 See Bronkhorst, Literacy and rationality, 20. 
Rational argumentation became one of the cornerstones of Buddhist scholasticism. The Vinaya provides us with early clues about how Buddhists cultivated this art. Monk-scholars came to understand what they were by arguing against what they were not. In this way their engagement with rivals bolstered their identity as Buddhists. How would Indian Buddhism have developed if it had never embraced a sedentary lifestyle, never adopted writing, and never engaged opponents in argument? It is difficult to say, but in the absence of these three developments it is difficult to imagine that we would have seen the emergence of elite scholarly communities. The three conditions - one social, one linguistic, and one philosophical - were central to the rise of Buddhist scholasticism.

\section{Part II}

What were Indian Buddhist scholastic communities like? What did monks study, and how did they study? We know a great deal about what scholastic communities were like in Tibet. For example, in the densas (gdan sa), the "seats of learning" of the Gelug school, we know that only about $20-30 \%$ of monks were "textualists « ( $d p e$ cha $b a$ ). The rest were engaged in work, administration, finances, rituals or other activities. We know that the 20 year-long curriculum that culminated in the formal degree of geshé (dge bshes) was structured around five major Indian treatises, their Indian and Tibetan commentaries, and a corpus of textbooks called yigchas (yig cha). And we know that the training involved memorization, debate, oral commentary on the text, and, to a lesser extent, silent reading (dpe klog rgyab pa). Prayer was also seen as indispensable to learning. In pre-1959 Tibet, when the term was in session, textualists spent about seven to eight hours each day debating, and about five to six hours in communal prayers.

Although we generally assume that these same activities - memorization, debate, oral commentary, etc. - were also central to Indian Buddhist education, the details of the Indian case are much less clear. True, we have the accounts of the Chinese pilgrims who visited the subcontinent, but these narratives are not very extensive. I recently came upon a short work of Jitāri (c. 950-1000 CE) called Purification on the Beginner's Path (Ädikarmikabhümiparișkara). ${ }^{59} \mathrm{~A}$ renowned scholar of the great Buddhist academy of Vikramaśila, Jitāri held the title mahāpaṇitita, or "great scholar". His Purification outlines a day in the life of a beginning bodhisattva-monk in a monastery. Given that Jitāi was himself a scholar, I had high hopes that this work would give us some clues about what scholar-monks did during a typical day, but rather than being descriptive, the text outlines, in a prescriptive fashion, how the beginning Mahāyāna monk should spend his day, from the time that he wakes up to the time that he goes to sleep. The activities that we normally associate with elite scholarly communities are barely mentioned. This is all Jitāri has to say about study: 
If, in between times, you have some free time, forsake your own happiness and strive to accomplish the welfare of others by explaining the Dharma etc...

During your mornings

exert yourself in the ten Dharma practices:

writing, reciting, etc.

Or else make sã̃ $c a k a s,{ }^{60}$ or help beings.

Morning, the best of times,

should not be squandered on purposeless things ${ }^{61} \ldots$

At twilight, as evening begins,

serve the guru properly.

[Then,] having washed your own feet,

meditate on concentration or insight

or else perform a really meaningful recitation.

Jitāri does not emphasize study, and when he does mention it, it is portrayed as an optional activity: »if you have time", then explain the Dharma; either engage in the ten Dharma practices like reading etc., "or else" make sāñcakas; meditate, "or else« recite something. The fact that Jitāri downplays learning might be a byproduct of his audience. Perhaps the work was meant as a guide for monks who lived in non-scholastic institutions. Whatever the case, Jitāri's Purification does not provide us with a robust picture of life in an elite Buddhist academy. So the quest continues to find out what the lives of scholar-monks were like. What texts did Indian Buddhist monks study? How did teachers teach these works? What did monks memorize and how did they memorize it? How did they debate?

60 A tsatsa (skt. sãñcaka) is a small clay figure of a deity or stūpa made from a mold. Creating sāñcakas was - and in Tibet still is - considered a way of purifying sin and creating merit.

61 Jitāri, Ādikarmikabhümiparișkara, 236b. 
We have bits of information, to be sure. For example, at Nālandā, monks were examined before being considered for membership in the community, and the vast majority - as many as eighty percent - failed to gain admission. ${ }^{62}$ Those who were admitted enjoyed one of the best educations anywhere in the Buddhist world, with classes on a variety of Buddhist and non-Buddhist subjects. The monastery attracted monks from China, Java, Korea, Central Asia, and Tibet. Estimates of the total number of monks at Nālandā vary wildly and the monastic population fluctuated in different periods, but it was probably in the thousands. About a hundred classes were offered each day over an eight-hour period by Nālandā's professor-monks who numbered more than $1000 .{ }^{63}$ The observance of monastic discipline was very strict. Students typically began by studying grammar and then went on to study logic and metaphysics (Abhidharma). The Chinese pilgrim Yijing (635-713) reports that the monks of Nālandā had a special technique that allowed them »to understand whatever they heard just once«. It apparently involved stabilizing the mind in some way using the alphabet as a mnemonic device. ${ }^{64}$ Nălandā's monk-professors were ranked according to the number of texts they had mastered (from ten to fifty texts). Over a thousand monks reputedly held the lower ten-text rank, but only ten monks had achieved the highest fifty-text status. We also know that the monastery was supported by royal endowments - perhaps as many as 200 villages and that once admitted, a monk never had to worry about his livelihood. Monk pandits were allotted a certain number of village families to provide them with salaries. The lowest professorial rank enjoyed the support of three families, and the highest of ten. ${ }^{65}$ Nălandā monks had a reputation as fabulous debaters. Yijing states that they could defeat non-Buddhists "as easily as driving away deer«, refuting their arguments as if they were »boiling water melting frost ${ }^{66}{ }^{6}$ Another Chinese pilgrim, Xuanzang (602-664), states that at Nālandā

Brilliant scholars of outstanding talent assemble in crowds to discuss questions of right and wrong... When they take part in a debate, they always win the case and sit on double mats to show their unusual intelligence. When they carry on arguments to refute [the heterodox], they render their opponents tongue-tied in shame. Their fame resounds through the five mountains and their repute spreads within the four quarters. They receive feudal estates and are prompted to higher rank, with their names written in white high up on the gates of their houses. ${ }^{67}$

62 Vidyabhusana, History of Indian Logic, 515 n. 1.

63 Bapat, 2500 Years of Buddhism, 186-188.

64 Li, Buddhist Monastic Traditions, 153.

65 Dung dkar, Bod kyi dgon pa, 70.

66 Yijing, as cited in Bapat, 2500 Years of Buddhism, 187.

67 Li, Buddhist Monastic Traditions, 150. 
Apart from what was just outlined, we know little else about the monastery, its curriculum, or its educational system.

Of the many characteristics of Buddhist scholasticism, we now turn our attention to three in particular. First, I try to piece together what a live debate might have looked like - not the day-to-day debates that monks practiced in their monasteries (we know little about this) but rather a grand debate between an important Buddhist scholar-monk and his opponent. Second, I treat one topic related to exegesis: how, over time, the commentarial corpus oscillates between periods of expansion and contraction, and the reasons for this. Finally, I discuss the role of prayer in scholastic learning.

\section{Debate}

Unfortunately, we have no sources that provide us with a blow-by-blow account of an actual, debate in classical India - at least none that are historically proximate to the debates themselves. ${ }^{68}$ The texts that do mention famous debates between Buddhists and non-Buddhists belong to a much later period, are preserved mostly in Chinese and Tibetan, and are of a hagiographical sort, and therefore highly embellished. ${ }^{69}$ That said, based on these accounts, and on a number of texts that describe the theory and practice of debate, I think it is possible to construct a picture of what a formal live debate - a stereotypically scholastic practice might have looked like in India. ${ }^{70}$

Debates were often convened by rulers ${ }^{71}$ sometimes for the pleasure of the court, sometimes for political purposes - for example, as a justification for backing one religion over another. But it was also possible for a scholar of one school or sect to directly challenge another. In this case, it was the duty of the king to make the arrangements for the debate and to act as an impartial judge (madhyastha). We have stories of non-Buddhist philosophers striking a drum, a wooden board, or a bell that hung at the entrance to Buddhist monasteries and demanding a debate. In one instance, a heterodox scholar conveys his desire to debate a Buddhist one by remaining standing, rather than sitting, while the monk was preaching. ${ }^{72}$

68 There is at least one work preserved in the Tengyur (Btsan 'gyur) that purports to be a record of "a great debate" between the Indian scholar Madhyamaka Simha (eleventh century) and some non-Buddhist rivals. This is the Brief Analysis of Different Views, Samkșiptanānädrstivibhäga. The colophon to the work states that the points that Madhyamaka Simha made during the debate "were memorized by scholars who passed them on from one to another... until they were finally redacted as a text« by a lay man named Tarośrimitra. The work may contain the essential arguments, but the process of redaction has wiped out many of the features of live debates that interest us, and it can hardly be considered a realistic, blow-by-blow account of a typical debate.

69 See Cabezón, Buddhist narratives.

70 Of course, the hagiographies of non-Buddhist scholars also provide us with valuable information. Solomon (Indian Dialectics, chap. 18) has discussed at great length the debate between Mandana and Sanikara in the eighth century, but as with the Buddhist narratives, this account was written centuries after the debate that it chronicles.

71 The Agamadambara, a play written by the ninth-century Kashmiri poet and philosopher Jayanta Bhatta (ninth century), is cast as a debate sponsored by the Kashmiri king Śankaravarman and his queen, suggesting that this was not uncommon. The work has been translated by Dezső, Much Ado About Religion. See also Solomon, Indian Dialectics 2, 848-850.

72 For the Indian and Tibetan sources of the sixth- or seventh-century Candrakirti/Candragomin debate, where this way of challenging an opponent is mentioned, see Cabezón, Buddhist narratives, 86 n. 33 . 
A challenge could not go unanswered. There are stories of monks convincing a royal patron to issue regulations to prevent their being challenged - for example, by prohibiting the striking of the drum or bell - but these strategies usually failed. Once a Buddhist monastery had been challenged, it had to produce one monk, its most accomplished scholar, to debate the challenger. If there was no one up to the task, a scholar could be invited from another institution. But if an individual monk was challenged, he had no choice but to accept. It is for this reason - for fear of being challenged and losing a debate - that Nālandā did not permit its inexperienced monks to teach outside the walls of the monastery. ${ }^{73}$ Major debates were formal events. They could only be convened in an assembly of scholars or in a royal court. Since scholars were generally eloquent and witty, debates undoubtedly served as a source of amusement for Indian royalty, just as they did, much later, for Tibetan rulers.

A debate was, in theory at least, supposed to be on a topic of importance and not on some trivial matter. ${ }^{74}$ During the debate, one of the parties, the »defender", put forward an argument: a thesis and one or more reasons that supported it. Sometimes the thesis statement could be quite long. The correct format of the thesis (sädhya or pratijña) differed according to different Indian schools, but at a minimum it had to have a premise (siddhānta) and a reason (hetu). The attacker then had to rehearse that same argument - repeating his opponent's thesis and reason - before launching into his rejoinder. The rejoinder (jäti or virodha) needed to be coherent, on point, and (most important) it had to cast doubt on the defender's thesis. Once the attacker had finished, the proponent of the original thesis responded with a rebuttal, but not before he too had summarized the attacker's rejoinder. ${ }^{75}$ Some accounts state that such back and forth volleys could go on for days, months, and even years - if both parties were learned and skilled in debate, of course. ${ }^{76}$ The debate was lost when one of the disputants contradicted himself, was forced to accept a position that contradicted the tenets of his own school, accepted a position that was deemed absurd, tried to change the subject, or was left speechless or babbling by the opponent. ${ }^{77}$ This account of a debate is admittedly oversimplified. For example, we have not mentioned the strategies and tricks (equivocation, false analogies, etc.) that could be used in debate, nor the tactics that might be used to parry such moves. Some texts state that when a debater identified one of these sophistic tricks, he won the debate; and, vice versa, that failure to identify the trick meant defeat. Be that as it may, three things are noteworthy as regards formal disputation. (1) The procedure was agonistic, with an attacker trying to defeat a defender. (2) Each side had to provide reasons for their positions. It was not sufficient simply to put forward a thesis without providing evidence for it. Although scripture might be used as evidence when the debate was between two

73 On this tradition, see Tāranātha, Rgya gar chos byung, 159: "Pandits who could endure a debate with a heterodox scholar taught outside the wall, those who could not taught inside."

74 See the section of the Yogäcārabhümi translated in Vidyabhusana, History of Indian Logic, 263-264.

75 The list of »defeats « (nigrahasthāna) from Vasubandhu's Tarkaśästra is found in Vidyabhusana, History of Indian Logic, 269.

76 Xuanzang states that one of Āryadeva's debates lasted for twelve days, and the debate between two great Buddhist scholars, Candrakirti and Candragomin, is said to have lasted seven years. See Cabezón, Buddhist narratives, 86-88.

77 This is the fate of the Buddhist monk who is defeated at the end of the first act of Jayanta Bhața's Agamadambara. Dezső, Much Ado About Religion, 80-81. 
members of the same religion, quoting from one's own sacred texts was obviously inappropriate when the opponent belonged to a different school. (3) Debates had a performative element. The debate manuals advise debaters to be confident, enthusiastic, and eloquent, and they state that debaters should be able to speak continuously without a break. (4) The ability to remember and repeat the opponent's arguments was crucial to the process. Being able to rephrase - or ideally to reproduce verbatim - the opponent's position was a sign of having a good memory, and therefore of intelligence. As previously mentioned, Nālandā monks are supposed to have practiced special techniques to achieve eidetic memory and were able to understand and reproduce what someone else said just from hearing it a single time. Of course, rephrasing the opponent's position also had practical consequences: it ensured that each party "heard " what the other was saying. ${ }^{78}$ More than one debate was lost for a monk's inability to properly rehearse his opponent's argument. Contrariwise, the Buddhist scholar Dharmapāla (fl. mid sixth century) is said to have won an important debate against a heterodox scholar simply by repeating verbatim his opponent's thesis statement (which in this case was the challenger's entire book!). ${ }^{79}$ The opponent apparently became so disheartened that he simply gave up. Some monks developed reputations as great debaters. For example, Dignāga was known under the epithet "debate-stud « (rtsod pa'i khyu mchog, *vādavrșa). ${ }^{80}$ Others, like Vasubandhu (fourth to fifth century CE), had a reputation for avoiding debates, suggesting that great scholars were not always great debaters.

The stakes of the competition were usually determined before the debate began and could be quite high, including physical punishment or even death. Whether debates "to the death" were hyperbole or not, losing a debate had consequences. Defeat could result in the mass conversion of the loser's entire community to the school of the winner, as purportedly happened in the aftermath of the Dharmakirti-Kumārila debate. ${ }^{81}$ The Buddhist scholar Āryadeva (second to third century $\mathrm{CE}$ ) is said to have been murdered by the disciple of an opponent he had defeated in debate. Although losing could have dire consequences, the rewards for winning could be great. Kings were known to award entire fiefs to winners.$^{82}$ Most of these historical details are found in the hagiographical literature. We therefore cannot be sure whether they represent historical fact. But even if there is reason to doubt the more magical elements of these tales - and there are plenty of those - the procedures of debates that they describe seem plausible enough.

78 It is possible that the requirement to repeat the other party's statement might have had to do with the widespread belief - as documented in the hagiographical sources - that one of the parties in the debate might be a demon or god, or have the backing of such a spirit. Supernatural beings of this sort are said to be incapable of repetition because, as Phyllis Granoff puts it, »the speech of the gods is without limitations with respect to time.« Hence, if one of the parties was incapable of repeating the argument of his opponent, it was seen as an indication that that person was a spirit in human guise, or was being fed information by a spirit. See Cabezón, Buddhist narratives, 80 .

79 Dharmapāla had a reputation for having an extraordinary memory. For example, Täranātha (Rgya gar chos byung, 167) tells us that "he could recite one hundred and eight large sütras."

80 Vidyabhusana, History of Indian Logic, 272. Solomon, Indian Dialectics 2, 833.

81 On other instances of the mass conversion of the loser's side to the winner's, see Solomon, Indian Dialectics 2, 848.

82 Xuanzang, a direct disciple of Sillabhadra, reports that the latter was awarded a fief, as was the master Gunamati (sixth century). See Li, Great T'ang Dynasty Record, 236-238, 241. 
Real life debates were undoubtedly messier than what later treatises suggest. Those trea-

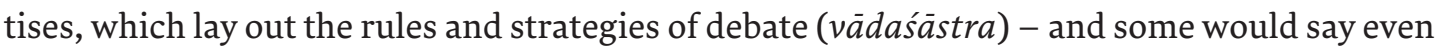
Indian logic and epistemology itself - evolved out of second-order, theoretical reflection on what took place in actual public exchanges. ${ }^{83}$ Although one must be careful not to characterize all of Indian Buddhism as equally interested in argumentation, Buddhists' defense of their views and their critique of heterodoxy was an important part of Indian scholastic culture. Tibetan monastic debate would differ in its procedural details and rules, but the seeds of this important aspect of Tibetan scholastic training were clearly sown in India.

\section{The Dialectic of Commentarial Abridgement and Expansion}

The Aștasāhasrikā, the Perfection of Wisdom in Eight Thousand Lines, is probably the earliest Prajñāpāramitā sütra, dating to the first century CE. ${ }^{84}$ The text was later shortened into various smaller formats, and expanded into larger ones. ${ }^{85}$ The largest is the version in One Hundred Thousand Lines. The smallest, that in a single syllable, the letter A. The idea that an entire scripture could be condensed or distilled into a single phrase, or expanded to mammoth proportions, has a long history in Buddhism. ${ }^{86}$

A similar dynamic is at work in regard to scholastic treatises or śästras. Just as some scriptures were considered the condensed pith or essence of others, some treatises written in verse (sütras or kärikas) were said to distill entire scriptural collections. Tibetans claim that the vast Perfection of Wisdom corpus is condensed in two sets of verse texts. The "wisdom « aspect of the sutras - the theory of emptiness - is said to be distilled in the treatises of Nāgārjuna, his "six philosophical works« (rigs tshogs drug). And the »method « aspect of the sūtras - Mahāyāna doctrines dealing with the stages of realization, etc. - is distilled in the Abhisamayālaṃkära, a work attributed to Maitreya. ${ }^{87}$ These verse works, sometimes called

83 The vādaśästras or debate manuals sometimes existed as independent works - Vasubdandhu is said to have written three such treatises - but discussions of debate (its purpose, types, strategies that enhance or detract from one's performance, fallacies that constitute defeat, etc.) are also treated in larger works. For instance, they are found in Asanga's Abhidharmasamuccaya and in the Yogācārabhūmi, which date to around the fourth or fifth century CE. See Gillon, Logic in classical Indian philosophy. For a discussion of two early texts that deal in part with debate - the Upãya Hrdaya and the Tarkaśāstra - see Tucci, Buddhist logic before Dignāga.

84 See Allon and Salomon, New evidence for Mahayana, 10.

85 The relative dating of the Perfection of Wisdom sütras is still a matter of dispute. Some scholars believe that the Diamond Sütra (Vajracchedikā) is the earliest and may have existed as an oral text from which the Asta was later elaborated. See Schopen, Figments and Fragments of Mahāyāna Buddhism, 31-32; and for a more recent discussion of the issues of chronology, Zaccheti, Prajñāpāramitā Sūtras.

86 For example, the later Tantric tradition claims that the first sentence of the Guhyasamajatantra, the so-called nidāna - »Thus have I heard: at that time the Lord >Body Speech and Mind of all the Tathāgatas` was dwelling inside the womb of an adamantine woman « - encapsulates the entire meaning of the Tantra. The same claim is also made of the first two syllables of the Tantra, e-vam (»thus«). The Guhyasamäjatantra is therefore considered an expansion or elaboration of that first sentence or first word. See Wayman, Yoga of the Guhyasamajatantra.

87 There was in Tibet considerable debate concerning whether all or only some of the Prajñäpāramitā Sütras were being explained in the Abhisamayālamkära. The Tibetan scholar Jetsun Chöki Gyaltsen (Rje btsun chos kyi rgyal mtshan, 1469-1544) cites these various opinions, and opts for considering the Abhisamayālamkāra to be a commentary on only three of the sütras: the Perfection of Wisdom in 100,000, in 25,000 and in 8,000 Lines. Rje btsun chos kyi rgyal mtshan, Rgyan 'grel spyi don rol mtsho 1 (stod bya), 25-27. 
»instructional texts « or upadeśas (man ngag), were prized for their ability »to generate understanding easily - that is, to permit one to effortlessly understand a vast body of material using few words « ${ }^{88}$ Synoptic works of this sort exist for most of the subjects of the scholastic curriculum. For instance, Gunaprabha's (sixth century CE) Vinayasūtra, is considered a distillation of the multi-volume Vinaya portion of the canon. Over time, these synoptic śästras came to possess as much authority as the original scriptures themselves, and for good reason: they could be easily memorized, giving monks access to the central ideas of the much larger corpus, and they could be easily taught, thus serving an important pedagogical function.

Earlier in this paper I suggested that many scholastic traditions are "proliferative«. The śa stric tradition is a fine example of this. Treatises written in verse gave rise to commentaries and subcommentaries, written mostly in prose. We need not go into the details, but over time, the commentaries on the verse texts increase in number and result in a literary corpus as large and as complex as the original canonical texts that had been condensed into verses. In other words, the saasstric corpus expands. This has a number of implications, some quite practical. For example, scholars needed to figure out how to work with multiple commentaries at once. We do not know how monks studied these multiple layers of commentary in India. Tibetan monks of the Lower Tantric College (Rgyud smad grwa tshang) were ingenious. They fashioned multi-tiered shokali (shog ka li) on which they could "hang" the different commentaries.

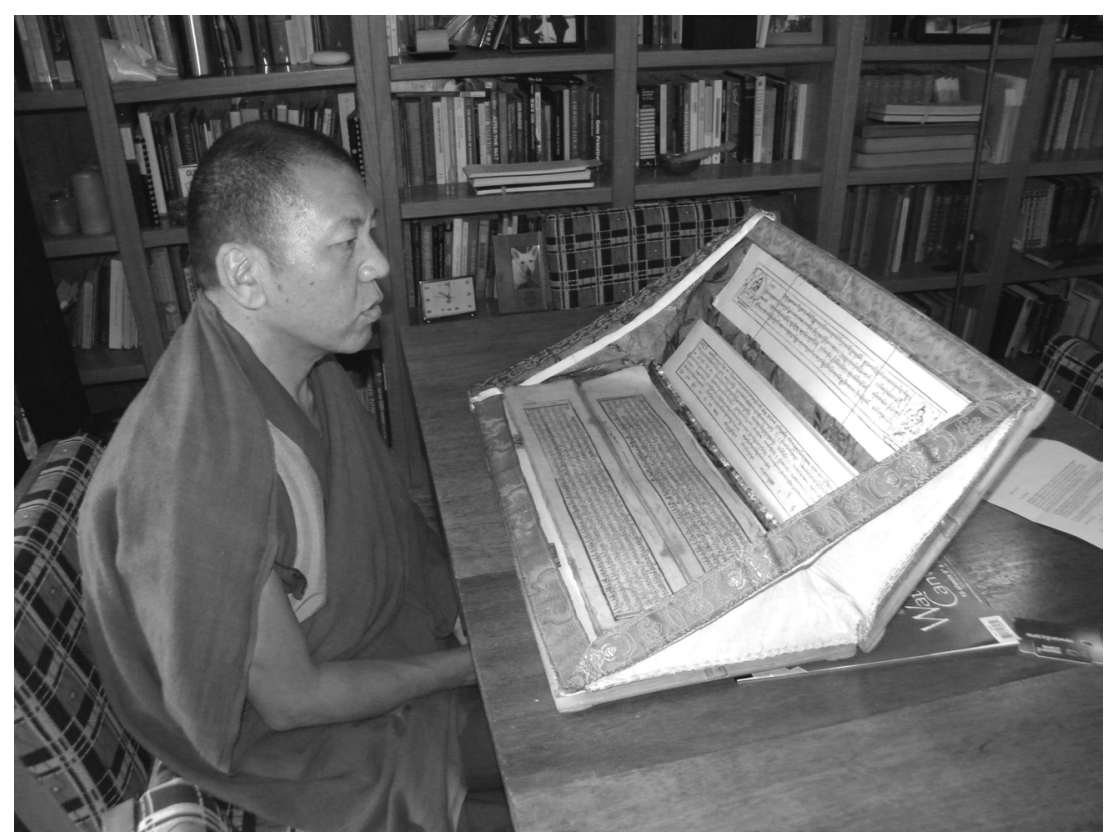

Figure 3: A monk of the Tantric College uses a text-stand (shokali) to read different strata of commentaries. Photo: J. Cabezón. 
This explosion of Buddhist commentarial literature begins in India and continues in Tibet. Eventually, the Tibetan commentarial corpus becomes so large that it becomes unmanageable and there is a need to condense $i t$. This gives rise to a genre of Tibetan verse works, called "verse summaries" or domtsig (sdom tshigs), that are distillations of the commentarial corpus. The pattern should by now be obvious. Let us call it the "accordion effect«. When a body of religious literature becomes too unwieldy, scholastics condense or summarize it in new treatises, but unable to control their proliferative impulse, they begin to comment on these summaries. Over time, this gives rise to a body of commentaries just as unwieldy as the original scriptures. This, in turn, gives rise to new distillations of the commentaries. In theory, this process could go on indefinitely, but in fact it seems to end with the Tibetan verse summaries, the domtsig. These latter texts were extremely popular in the Tibetan academies, especially in studying Vinaya and Abhidharma. The Tibetan verse summaries are the end of the process, or maybe it is just a matter of time before it all starts anew.

\section{The Role of Prayer in Scholastic Learning}

Jitāri's Purification - the work that outlines how a beginning Mahāyāna monk ought to spend his day - may not have much to say about how monks studied, but it has a lot to say about how they ought to practice.

Once the sun has come up,

wash yourself etc.,

and then prostrate to the stūpa, offer the mandala,

and confess sins, etc., doing these practices extensively.

Especially, go for refuge,

and generate bodhicitta so that it is firm.

Then, after doing some circumambulations,

prostrate before the guru,

the elder, and the dharma preacher.

Speak pleasantly to them with a smile,

and, exerting yourself, do whatever they need you to.

If, in between, you have some free time,

give up your own happiness, and exert yourself so as to accomplish the welfare of others by explaining the Dharma etc.

Take your breakfast (khye'u sus) ${ }^{89}$

as the Ratnamegha advises.

Divide the food into four parts and eat [just one].

Share the remainder of your food and drink with the poor. ${ }^{90}$

89 The term khye'u sus, which translated Sanskrit purobhaktikä, is found throughout the Vinaya, but not in the Ratnamegha.

90 Prajñākaramati, Bodhicaryāvatārapañjikā, fols. 101b-102a: "Divide whatever alms you have received into four parts ... Give the first part to the beings who have fallen into the lower realms. Give the second part to the destitute. Give the third part to those who perfectly practice the monastic life. Eat the fourth part yourself. Eat the food without any desire, without attachment, without craving, without clinging. Eat just enough for the maintenance of the body, just enough to save it. Eat just enough so that you do not become emaciated, but not so much that you gain weight." 
During morning times

exert yourself in the ten dharma practices:

writing, reading/reciting, etc.

Or else make tsatsas, or help beings.

Morning, the holiest time,

should not be wasted on purposeless things.

During the noon hours, meditate a little

on love and on the recollections.

Then again make prostrations etc.

doing what you did earlier, but more extensively.

Mid-afternoon is the time

to take rest and associate with holy beings,

and to enjoy excellent verses about reaching the truth

and having revulsion for existence.

In the late afternoon meditate again,

but now on concentration and insight,

and prostrate to the stūpa, etc.

At twilight, as evening begins,

serve the guru properly.

Then, having washed your own feet

meditate on concentration or insight

or else do a really meaningful recitation.

Once the first part of the night is finished,

go to sleep in the appropriate fashion

with the proper mental attitude.

Strive, both day and night,

to engage in various virtuous acts

as explained in the Subahupariprcchà

and in the Ratnāvali.

Doing so, you will obtain the "stage of warmth « etc.

even in this very life

The great emphasis that Jitāri places on religious practice - on gaining merit and purifying sin - would not have come as a surprise to the monks who studied in Tibet's great academies. Even though textual training was the chief mission of Tibet's scholastic institutions, their broader goal was the formation of well-rounded individuals. To be learned ( $m k h a s p a$ ) was clearly important, but so too was being of noble character (btsun pa) and being morally upright (bzang po). Prayer was considered essential to the formation of respectable, ethical subjects, balancing the rigorous training of the intellect with training of the heart. But prayer was considered essential to monks' success even in academic pursuits. Tibetans believe that a person's talents can be enhanced and their limitations or obstacles dispelled through sagjang (gsag sbyang), the accumulation of merit and the purification of sin. The many hours of prayer that Tibetan monks did (and still do) every day fall under the broad rubric of sagjang. Purification and merit-making are believed to dispel obstacles like illness, but also to enhance a monk's ability to learn. For example, Tibetan teachers often require their young charges to recite the mantra of Mañjuśrī, especially the deity’s "seed syllable, « Dhīh. This is believed to increase a boy's intellectual capacities and to prepare him for the arduous scholarly path that lies ahead. 
Sanskrit texts preserved in Tibetan translation suggest that Indian monks also recited mantras, prayers, and praises, and performed visualizations and rituals to eliminate obstacles, cure illnesses, and »enhance the intellect and wisdom " (prajñäbuddhivardhana).$^{91}$ There are also practices to be done before reading. For example, in a short work entitled $A$ Ritual to Be Enacted Before Recitation and Reading, the Indian scholar-saint Atiśa (982-1054 CE), describes a visualization and prayer to be done before engaging in these activities. ${ }^{92}$ And one assumes that stand-alone prayers - like the Prayer of Good Conduct (Bhadracaryāpranidhāna) and the Maitreya Prayer (Maitreyapranidhāna) - were part of monastery liturgies, just as they were in Tibet. But because it is impossible to infer the prayer life of Indian monasteries from the prayer texts that have survived, we can only surmise that Indian Buddhist scholastic institutions had a rich prayer life.

We have a much clearer picture about Tibet. Monks in Tibet's great monastic academies believe that there is a direct correlation between prayer and their success as scholars. There is a saying at Sera Monastery, "For every handful of study, six of ritual. ${ }^{93}$ This is an exaggeration - the ratio was actually about one-to-one - but the point is clear: learning requires prayer. ${ }^{94}$ Some monks would even claim that there is a direct correlation between prayer and a monk's success in his studies. An eminent contemporary monk scholar, Ganden Tri Rinpoché Lozang Tenzing (Dga' ldan khri rin po che blo bzang bstan 'dzin, b. 1934), opines about why the level of study in the Indian exile is not on a par with that of old Tibet.

In Tibet the duration of the evening prayer sessions was very, very long. The fact that it is shorter in exile means that monks are not able to recite enough prayers [to support] their study. In earlier times we recited the Praises to Tärā twenty-one times. These days, it is only recited three times. In earlier times monks recited the Heart Sütra nine times; nowadays, only three times. So the prayer sessions are not as effective... Because the internal prayers are not performed nearly as well [today], there are more [external] obstacles to our studies. ${ }^{95}$

If nothing else, Tri Rinpoché's words bespeak the importance of prayer in monasteries like Sera. When we, as historians of elite religious institutions, forget about the role of prayer in the lives of scholar-monks, we end up with a skewed picture of scholastic communities. The Buddhist academies of India and Tibet were not, of course, like modern, secular universities, and prayer is one of the things that distinguishes them.

91 The canonical collection known as the Dhäranīs contains short works for protection and to dispel obstacles. Several texts for enhancing intelligence are also preserved in the Tibetan canon (L 549; and D 3191, 3447, and 3472), as is a work by Ajitamitragupta (twelfth century) called How to Make Your Students Smart (Sișyaprajñotpādana).

92 Dīpamkaraśrijināna, Adhyayanapustakapāthanapuraskriyāvidhi. The purpose of the practice is not so much to enhance learning, as to cultivate a correct motivation. There is an equivalent practice, written from a Tantric perspective, called How to Read a Book, composed by Dānaśila (possibly ninth century), the Pustakapāthopāya. The work prescribes a practice to be performed before reading a text on behalf of a patron.

93 This saying is found in the Great Exhortation, Tshogs gtam chen mo, 57.

94 And vice versa, failure to pray can have dire consequences for one's success as a scholar. The Great Exhortation - a supplementary set of regulations and advice to monks that belongs to the Ché (Byes) College of Sera - states that when monks offer the ritual cake (gtor $\mathrm{ma}$ ) during the evening prayers, »the compassionate deity walks around the debate courtyard (chos $r w a$ ) to check on the monks. Those present at the gathering, receive his blessings. And those absent without an excuse are punished by him." Tshogs gtam chen mo, 59.

95 The remarks are from an interview I conducted in Madison, Wisconsin in 2003. 


\section{Part III}

Broadly speaking, the challenges that scholastic communities faced in India were of two types: (1) theological-ideological, and (2) economic-political. Indian Buddhism, as we have seen, is ambivalent about elite learning. Doctrinal theorizing, philosophical speculation, the study of the classical "sciences" (vidyästhäna), and debate have sometimes been criticized as fruitless. This broad-ranging ambivalence was augmented by more specific critiques of learning. The most important of these - and the one I focus on here - is the critique mounted by the apophatic traditions. This is not as much about the social and psychological dangers of study - that it distracts from practice, that it leads to pride, etc. - as it is a skepticism about the very medium of scholarship, language itself: the tendency of language to reify the world, to create false dichotomies, and to fall short of capturing the nature of reality. Some of this skepticism is relatively benign. For example, Asanga's (fourth century) Seventy Stanzas, a synopsis of the Perfection of Wisdom, claims that no Buddha ever taught anything, that there is neither Dharma nor non-Dharma, neither teaching nor teacher; that what the Buddha does teach is inexpressible and like an echo; and that the truly wise person is the one who sees all knowledge as empty. ${ }^{96}$ But when push comes to shove, even a text that espouses a radically apophatic and ineffabilist perspective, as Asanga's Seventy Stanzas does, nonetheless extols the Dharma as the "supreme gift" and stresses the importance of study and learning. The Dharma may be beyond words, but

memorizing the Dharma [oneself] and teaching it [to others] is not useless because it allows one to accumulate a great deal of merit... There are three things to do in regard to the words of the Dharma: memorizing them, listening to them, and spreading them. The meaning [of the Dharma] is gleaned by studying [those words] under someone else and by critical contemplation. ${ }^{97}$

Hence, despite the Seventy Stanzas' misgivings about language, it never repudiates the importance of memorization, study, analysis, and teaching. The critique is therefore benign. It was not meant as a challenge to scholastic communities or to their mission.

The more serious challenge emerges from a later strand of apophaticism. Beginning in the eighth century, during the heyday of Indian Buddhist scholasticism, the Buddhist siddhas - the iconoclastic saints of the esoteric, Tantric tradition - posed a serious ideological challenge to scholastic learning and the institutions that propagated it. Some of the Buddhist siddhas - Virūpa (seventh-eighth century), Nāropa (eleventh century), Maitripa (1007-1085), etc. - were, earlier in their lives, renowned scholars at academies like Nālandā. A vision, religious experience, or chance encounter causes them to glean that for all their learning, they have failed to realize the fundamental truths of Buddhism. They then leave the monastery, adopt an antinomian lifestyle, become wandering yogis, and achieve enlightenment. In the siddhas' life stories, the scholastic institutions that they leave behind are often portrayed as places of dry learning where monks are obsessed with doctrinal minutiae and abstruse philosophy. Siddhas, by contrast, expressed their realization in the language of poetry or songs $($ doha $)$. The critique of scholasticism - of scriptural learning, analysis, and distinction-making - is often explicit in the dohās, as in this verse of Maitripa.

96 The work, the Triśatikāyāh Prajñjāpāramitā Kärikāsaptati, has been edited and translated by Tucci in Minor Buddhist Texts, 3-192.

97 Ibid., vv. 16 and 37, pp. 61, 72. The translation is my own. 
Ignorant are those who speak

of things in their particularities.

All forms of analysis and all the six views

come together on this ship.

When you hold firmly onto this ship of mind,

you will find freedom on other shores.

Apart from this, O yogi

there is no other method! $!^{98}$

Or better yet, consider this passage from Maitripa's Interlinear Commentary on the Treasury of Dohās (Dohākoșapañjikā), ${ }^{99}$ which presents us with glosses on Saraha's Dohākośa (here, italicized).

[I, the Archer, Saraha, say, that whoever possesses a sky-like mind never thinks of emancipation. Those who renounce the blissful reality and only engage in bodily asceticism are called novices, monks, and elders. These bandés first ordain.] Some then spend their time explaining the sütras. Some monks, driven by lust for wealth, explain truths [found in] previously unknown [i.e. apocryphal] suttras; they go to hell. I have seen others become emaciated as the result of the way they tax their minds. ${ }^{100}$ [This refers to the textual tradition of the epistemological treatises. ${ }^{101}$ Some, due to a lack of learning, construct many theories about the Dharma, which is also incorrect. That is to say, some ascetics examine a multitude of scriptural books and then argue about them; ignorant of the meaning of the scriptures, they are reborn in the realm of sinners. Thus, their bodies become emaciated from the way they tax their minds, and they become sick ... Some are concerned with the explanations of the meaning of the four ... [philosophical schools] - that is, they concern themselves with the Vaibhāsika, Sautrāntika, Yogācāra and Madhyamaka. But that's just a bunch of words. There is no reality [to be found there], and so [explaining them] is pointless... Because they preoccupy themselves with refuting one another, they go to hell. Some, while deliberating and examining, fall from the path. Some lose their desired goal as the result of deliberation and analysis, for the path is beyond conceptual analysis.

This is obviously a critique of the scholarly practices of elite monks, who, because of their preoccupation with words and analysis, fail to understand the natural state, the true nature of things. Of course, there is a certain irony here since Maitripa elaborates his critique of scholasticism in a commentary that uses words to explain other words, and that employs analysis in the service of argument. Problems of consistency aside, the siddha tradition was clearly an important theological challenge to scholasticism. Indian Buddhist scholasticism - at least the scholasticism of the exoteric variety - begins to wane after the eighth century.

98 Maitrīpa, Cittamātradrsțti, fols. 48b-49a.

99 Advayavarjra, Dohākoșapanjikā, fols. 184b-185a. The line rdzas kyi srid pa on fol. 184.b.4 has been emended to read rdzas kyi sred pa. The work is a commentary on Saraha's Dohäkoṣagiti.

100 Pañjikä: la la bsam khral mang pos bskams pa mthong. Saraha's root text has a completely different line: la la ro gcig sems kyi tshul 'dzin mthong, "I see others holding that the single taste (ekarasa) is an aspect of the mind."

101 This line is found only in the root text and is missing in the Pañjikā. It reads, in Saraha's work, de ni gzhung lugs tshad ma'i bstan bcos yin. It is possible that the line was originally someone's note ( $m c h a n$ ) and later mistakenly incorporated into the text. 
The siddhas were not solely responsible for its demise, but their writings suggest that from the eighth century the scholarly communities of north India were increasingly criticized for over-specialization, for emphasizing theory over practice, and for being more concerned with the letter than with the spirit of Buddhism. Critiques of this sort can only have made life more difficult when these scholarly communities faced other, material challenges.

Indian Buddhist institutions of learning have always faced different political and economic challenges - loss of patronage, inhospitable kings and ministers, active persecution, military invasion, etc. Sometimes these communities managed to bounce back; but by the end of the twelfth century they had more or less collapsed for good and Buddhism died out in India. We do not have many sources about how scholastic communities faced these types of challenges. The final lines of the Tibetan translation of the Vinaya Uttaragrantha is an important exception. The work quotes (or perhaps paraphrases) another unnamed commentary to explain how the text became corrupt, and in so doing it allows us to glean some of the challenges that scholastic communities faced and how they responded to them.

The Brahmin king Pusyamitra (Rgyal bshes) ${ }^{102}$ destroyed the ancient scriptures of our deceased teacher [the Buddha] out of anger, and did great harm to the teachings. He also destroyed stūpas, burnt Buddhist monasteries, and killed monks. Piling up the books of the Buddha's word, he set them on fire. But then, over time, monks again brought together all the books of the Tripitaka from various places. In the process of recompiling them in Mathura, the Uttaragrantha was not found. Hearing that there was a monk in Kashmir who could still recite the Uttaragrantha, [the monks from Mathura] traveled to Kashmir, met the monk, and said, "We have heard that you can recite the Uttaragrantha. Please recite it." The monk replied, »I remember some portions [of the work] but not others." So they said, "Please speak whatever portions you remember." And he recited it as instructed. Those monks thought, "Let us make a temporary redaction of the text [based on the parts he recited] and later add [the missing portions] by analyzing the words and their meaning. « So thinking, they wrote it down. But later on, distracted by other work, they did not finalize it for a long time. [Meanwhile,] other monks from other places had also recited [the work, but] differently. It is for this reason, because the oral recitations [of the text] had degenerated - that is, because the Uttaragrantha was recited in different ways and had different meanings... that the Uttaragrantha became corrupt. But it is well known that those portions of the original text recouped from what existed in the minds of a few Magadhan monks and from what could be found among the ashes - that is, from [the portions of the texts that] had not been burned - were not lost and are accurate. ${ }^{103}$

102 The Sunga defeat of the Mauryan dynasty c. 185 BCE is said to have ushered in a persecution of Buddhism. The Aśokāvadāna speaks of a Pușyamitra who killed the last Mauryan emperor, usurped the throne, and persecuted Buddhism, killing the monks of Pātaliputra. But there can be no question of burning books at this time because writing was not yet widespread. The Tibetan historian Täranātha also speaks of a persecution by a Brahmanical king Pusyamitra, but situates this just before the first Hun invasions of Magadha in the fifth century CE. And indeed we know that a tribal group called Pusyamitra attacked the Gupta empire c. 455, toward the end of the reign of Kumāragupta I. They were defeated by the latter's son Skandhagupta. It is possible that Buddhist sources - including the colophon translated here - conflated the earlier Pusyamitra (a king) with the much later tribe by the same name. In any case, if there was a persecution of Buddhism of the kind mentioned in this passage, it likely took place in the fifth century and was the result of warfare between the Guptas and their disloyal vassals, the Puṣyamitras. Some Mahāyāna sūtras - for example, the Daśacakra Kșitigarbha - go into great detail concerning the sin that kings and ministers incur when they "destroy the Tripitaka, burn it, and turn it into ash, « implying, of course, that monks feared royal persecution and the destruction of their texts.

103 Vinaya Uttaragrantha, fols. 138a-138b. I have not identified the commentary from which this passage is quoted, and, indeed, it may no longer exist. 
Indian Buddhist monasteries had been collecting books since the first centuries of the Common Era. Over time, their libraries grew, sometimes (as in the case of Nālandā) to mammoth proportions. This passage tells us that the corpus of physical texts could be easily destroyed, but that monks also rose to the challenge of recouping what they had lost. If written texts were lost - due to persecution, but also to fire, decay, etc. - they could be rewritten on the basis of the oral recitations that monks still preserved. Orality therefore served as a kind of mechanism of redundancy, a failsafe or backup. Reconstituting a lost text was no straightforward matter, however, since the oral recitations were incomplete or inconsistent. A monk might be able to recite one portion of a work but not another, and what he did recite did not always jibe with what other monks recited. While it was no straightforward thing to reconstruct lost texts, the Uttaragrantha colophon bespeaks the determination of monks to maintain the physical canon. In the end, the elite scholarly communities of India disappeared, but their traditions lived on in Tibet. In the Land of Snows, Buddhist monasteries proved more resilient. Despite two major persecutions - one in the ninth century by the Tibetan king Langdarma (Glang dar ma), and one in the twentieth century by the Communist Chinese - the great monasteries of Tibet continue to flourish, a testament to their resiliency. That Buddhist monasteries continue to transmit their textual traditions despite political and economic hardships supports a point made earlier: that scholastic communities are extremely effective at preserving their traditions of learning.

This paper has attempted to bring a more historical and social dimension to my earlier work on scholasticism, which, as stated at the outset, was more synchronic and structuralist. It was not a foregone conclusion, I have suggested that Indian Buddhism should have taken a scholastic turn - that certain historical and social conditions had to be met before specialized communities of learning could emerge within Buddhism. But once established, their unique character reflected their cultural and intellectual milieu. And when they began to die out, they did so under specific political and economic conditions. Part I of this paper explored three moments in the history of Indian Buddhism that made the emergence of scholasticism possible. Stability, writing, and adversarial argumentation might not, in general, be sufficient for the emergence of communities dedicated to specialized learning, but in the case of Buddhism they were necessary. Part II explored three aspects of mature scholasticism in India and Tibet. We do not know exactly how live debate was practiced in India, but we can adduce a general picture of what it was like. Given what was at stake in debate contests, it is not surprising that Buddhists should have dedicated considerable energy to the art of argumentation. Commentary too has long been understood as central to monastic education in both India and Tibet; it has functioned both to summarize and to expand on other texts. In this paper I have suggested that, when we take a long historical view, the commentarial tradition alternates between periods of contraction and expansion. This dialectic is the result of two competing aspects of scholasticism: a commitment to pedagogy (which demands summaries of the canon) and proliferativity (the tendency to always want to say and include more). Unlike debate and commentary, the role of prayer and ritual in Buddhist scholasticism has not received much attention in Europe and North America. Although much more remains to be done, I have suggested that it is crucial to understanding the identity of Buddhist scholarly communities as religious institutions. Finally, in Part III, the paper points to some of the challenges - ideological and political - that Buddhist scholastic communities faced in India. Although these factors were not solely responsible for the disappearance of these communities in India, they contributed to their demise. Broadly speaking, this paper raises the questions of what conditions lead to the emergence of scholasticism, what form 
scholastic traditions take once they have been formed, and what factors bring about their end. While this essay will not be the last word on Buddhist scholasticism, it hopefully suggests how historical and social factors are indispensable to understanding the arising, abiding, and destruction of Buddhist communities of learning.

\section{Acknowledgements}

The author wishes to thank the "Rethinking Scholastic Communities across Medieval Eurasia" project of the Austrian Academy of Sciences, and especially Professor Birgit Kellner, for her invitation and for her response to this paper. 


\section{References}

Advayavajra (aka Maitripa), Dohākoșapanjikā, Do ha mdzod kyi dka' 'grel, D 2256, fols. 18ob-207a.

Aggi Vacchagotta Sutta, Majjhima Nikāya 72.

Ajitamitragupta, Sisyaprajñotpādana, Slob ma la shes rab bskyed pa, D 2830, fols. 175a-176a. Ali, Ihsan and Muhammad Naeem Qazi, Gandharan Sculptures in the Peshawar Museum (Life Story of the Buddha) (Mansehra, Pakistan, 2008).

Allon, Mark, The oral composition and transmission of early Buddhist texts, in: Peter Connolly and Sue Hamilton (eds.), Indian Insights: Buddhism, Brahmanism, and Bhakti. Papers from the Annual Spalding Symposium on Indian Religions (London, 2002) 39-61.

Allon, Mark and Richard Salomon, New evidence for Mahayana in early Gandhāra, The Eastern Buddhist, New Series 41/1 (2010) 1-22.

Anālayo, Bhikkhu, Dìrgha-ägama Studies (Taipei, 2017).

Asañga, Triśatikāyah Prajñjāpāramitā Kärikāsaptati, ed. and trans. Giuseppe Tucci, Minor Buddhist Texts 1 and 2 (Delhi, 1986) 3-192.

Aștasāhasrikā Prajñāpāramitā, ed. P. L. Vaidya (Darbhanga, 1960). Also Shes rab kyi pha rol tu phyin pa rgyad stong pa, L 11, 2 vols.

Atiśa (aka Dīpamkaraśrijñ̄āna), Ratnakarandodghata nāma madhyamakopadeśa, Dbu ma’i man ngag rin po che'i za ma tog kha phye ba, D 3930, fols. 96b-116b.

Bapat, P. V., 2500 Years of Buddhism (New Delhi, 1956).

Bhikșnivinayavibhanga, Dge slong ma'i 'dul ba rnam par 'byed pa, L 5, fols. 35a-460a.

Bodhi, Bhikkhu, The Buddha's Teachings on Social and Communal Harmony: An Anthology from the Pāli Canon (Boston, 2016).

Bollee, Willem Boudewijn, Adda or the oldest extant dispute between Jains and heretics (Sūyagadia 2,6): Part two, Journal of Indian Philosophy 27 (1999) 411-437.

Bronkhorst, Johannes, Literacy and rationality in Ancient India, Asiatische Studien/Études Asiatiques 56/4 (2002) 797-831.

$\mathrm{Bu}$ ston rin chen grub, Shes 'grel rgya cher bshad pa lung gi snye ma (Sarnath, 1979).

Byang chub lam rim chen mo dang 'brel ba'i ser byes mkhas snyan grwa tshang gi tshogs gtam chen mo (Bylakuppe, 2012).

Cabezón, José Ignacio, A Dose of Emptiness: An Annotated Translation of the sTong thun chen mo of mKhas grub dge legs dpal bzang (Albany, 1992).

Cabezón, José Ignacio, Buddhism and Language: A Study of Indo-Tibetan Scholasticism (Albany, 1994).

Cabezón, José Ignacio, Scholasticism: Cross-Cultural and Comparative Perspectives (Albany, 1998).

Cabezón, José Ignacio, Vasubandhu's Vyākhyāyukti on the authenticity of the Mahāyāna Sütras, in: Jeffrey Timm (ed.), Texts in Context: Traditional Hermeneutics in South Asia (Albany, 1999) 221-243.

Cabezón, José Ignacio, Buddhist narratives of the great debates, Argumentation 22 (2008) 71-92.

Cabezón, José Ignacio and Penpa Dorjee, Sera Monastery (Boston, 2019).

Cula Malunkya Sutta, Majjhima Nikāya 26.

Dānaśila, Pustakapāthopāya, Glegs bam klag pa’i thabs, D 4252, fol. 249 a.

Daśacakra Ksitigarbha, Sa'i snying po 'khor lo bcu pa'i mdo, L 240, fols. 154a-182a. 
De Simini, Florinda, Of Gods and Books: Ritual and Knowledge Transmission in the Manuscript Cultures of Premodern India (Berlin, 2016).

Dezső, Csaba, Much Ado About Religion by Jayanta Bhatța (New York, 2005).

Dīpamkaraśrijiñāna (aka Atiśa), Adhyayanapustakapāțanapuraskriyāvidhi, Kha ton dang glegs bam bklag/klog pa'i sngon du bya ba'i cho ga, D 3975, fols. 255b-256a.

Ducoeur, Guillaume, Le bodhisattva à la salle d'écriture: Histoire rédactionnelle et datation, Revue de l'Histoire des Religions 231/2 (2014) 385-424.

Dung dkar blo bzang 'phrin las, Bod kyi dgon pa khag gcig gi dpal 'byor gnas tshul la dpyad pa, in: Dung dkar blo bzang 'phrin las kyi gsung rtsom phyogs bsgrigs (Beijing, 1997) 67-78.

Falk, Harry and Seishi Karashima, A first-century Prajñāpāramitā manuscript from Gandhāra - parivarta 5 (Texts from the Split Collection 2), Annual Report of the International Research Institute of Soka University for the Academic Year 201216 (2013) 97-169.

Franco, Eli, The Spitzer Manuscript: The Oldest Philosophical Manuscript in Sanskrit, 2 vols., Beiträge zur Kultur- und Geistesgeschichte Asiens 43 (Vienna, 2004).

Gellner, Ernest, Concepts and community, in: Ernest Gellner (ed.), Relativism and the Social Sciences (Cambridge, 1989) 167-186.

Gillon, Brendan, Logic in classical Indian philosophy, in: Edward N. Zalta (ed.), The Stanford Encyclopedia of Philosophy (Fall 2016 Edition). Accessed on 26 September 2020: plato. stanford.edu/archives/fall2016/entries/logic-india/.

Hargreaves, Harold, Masterpieces of Oriental art 17: Representations of the Bodhisattva going to school in Gandhāran reliefs, Journal of the Royal Asiatic Society of Great Britain and Ireland 3 and 4 (1951) 131-133.

Jitāi, Ādikarmikabhümiparișkara, Las dang po pa'i sa sbyang ba, D 3945, fols. 235a-237a.

Kalyāṇadeva, Bodhisattvacaryāvatārasamskāra, Byang chub sems dpa'i spyod pa la 'jug pa' legs par sbyar ba, D 3874, fols. 1b-9ob.

Li, Rongxi (trans.), The Great T'ang Dynasty Record of the Western Regions of Xuanzang (Berkeley, 1996).

Li, Rongxi, Buddhist Monastic Traditions of Southeast Asia: A Record of the Inner Law Sent Home from the Southern Seas by the Sramana Yijing (Berkeley, 2000).

Madhyamaka Simha, Saṃksiptanānädrștivibhāga, Lta ba tha dad pa rnam par phye ba mdor bsdus pa, D 3898, fols. 1b-7b.

Maitreya, Madhyāntavibhāga, Dbus danmg mtha' rnam par 'byed pa, D 4021, fols. 40b-45a.

Maitreya, Mahāyānasūtrālaṃkāra, Theg pa chen mo mdo sde'i rgyan, D 4020, fols. 1b-39a.

Maitripa (aka Advayavajra), Cittamātradrșți, Sems tsam gyi lta ba, D 2435, fols. 48b-49a.

Manné, Joy, The Dìgha Nikāya debates: Debating practices at the time of the Buddha, Buddhist Studies Review 9/2 (1992), 117-136.

Matilal, Bimal Krishna, Logic, Language and Reality: An Introduction to Indian Philosophical Studies (Delhi, 1985).

Nance, Richard F., Speaking for Buddhas: Scriptural Commentaries in Indian Buddhism (New York, 2012).

Negi, J. S., Tibetan-Sanskrit Dictionary (Sarnath, 2002).

Prajñākaramati, Bodhicaryāvatārapañjikā, Byang chub kyi spyod pa la 'jug pa'i dka' 'grel, D 3872, fols. 41b-288a.

Rje btsun chos kyi rgyal mtshan, Rgyan 'grel spyi don rol mtsho, 2 vols. (Mtsho sngon, 1989). Rta tshag ye shes blo bzang bstan pa'i mgon po, Klong rdol bla ma'i rnam thar (Lhasa, n.d.).

Sabbasava Sutta. Majjhima Nikāya 2. 
Săftoiu, Răzvan, Constructing and negotiating identity in dialogue, Language and Dialogue 5/1 (2015) 6-22.

Sañgiti Sutta. Dïgha Nikāya 33.

Śāntideva, Bodhicaryāvatāra, Byang chub sems dpa'i spyod pa la 'jug pa, D 3871, fols. 1b-40a. Saraha, Dohäkoṣagiti, Do ha mdzod kyi glu, D 2224, fols. 70b-77a.

Schoening, Jeffrey D., Sūtra commentaries in Tibetan translation, in: José Ignacio Cabezón and Roger R. Jackson (eds.), Tibetan Literature, Studies in Genre (Ithaca, 1996) 111-124.

Schopen, Gregory, Figments and Fragments of Mahāyāna Buddhism in India (Honolulu, 2005).

Schopen, Gregory, Buddhist Nuns, Monks, and Other Worldly Matters: Recent Papers on Monastic Buddhism in India (Honolulu, 2014).

Shaw, Julia, Buddhist monasteries and monasticism in Ancient India (University College London). Accessed on 26 September 2020: www.ucl.ac.uk/archaeology/research/directory/ monasteries_shaw.

Skilling, Peter, Redaction, recitation, and writing: Transmission of the Buddha's teachings in India during the early period, in: Stephen C. Berkwitz, Juliane Schober, and Claudia Brown (eds.), Buddhist Manuscript Cultures: Knowledge, Ritual, and Art (London, 2009) 53-75.

Solomon, Esther A., Indian Dialectics: Methods of Philosophical Discussion, 2 vols. (Ahmedabad, 1978).

Stoneman, Richard, The Greek Experience of India (Princeton, 2019).

Tajadod, Nahal, The role of Iranians in the spread of Buddhism, Manichaeism and Mazdaism in China, Diogenes 54/4 (2003) 61-66.

Tāranātha, Dam pa'i chos rin po che 'phags yul ji ltar dar ba'i tshul gsal bar ston pa dgos 'dod kun 'byung (Rgya gar chos 'byung) (Dharamsala, 2005).

Tucci, Giuseppe, Buddhist logic before Dignāga, Journal of the Royal Asiatic Society of Great Britain and Ireland 7 (1929) 451-488.

Upali Sramon, Elements of a Buddhist literary theory as depicted in Pali literature, Journal of the Royal Asiatic Society of Sri Lanka, New Series 57 (2011) 19-39.

Vasubandhu, Madhyāntavibhāgabhāşya, Dbus dang mtha' rnam par 'byed pa'i 'grel pa, D 4027, fols. 1b-27a.

Vidyabhusana, Satis Chandra, A History of Indian Logic (Delhi, 1978).

Vinaya Kșudrakavastu, 'Dul ba phran tshegs kyi gzhi. L 6, 2 vols.

Vinaya Uttaragrantha, 'Dul ba gzhung bla ma, L 7, fols. 1b-139a.

Vinayavastu, 'Dul ba gzhi. L 1, 4 vols.

Vinayavibhainga, 'Dul ba rnam par 'byed pa. L 3, 4 vols.

Walser, Joseph, Nāgārjuna in Context: Mahāyāna Buddhism and Early Indian Culture (New York, 2005).

Wayman, Alex, Yoga of the Guhyasamajatantra: The Arcane Lore of Forty Verses, A Buddhist Tantra Commentary (Delhi, 1977).

Xing, Guang, Rational argumentation in early Buddhism, in: Siegfried C. A. Fay and Ilse Maria Bruckner (eds.), Buddhism as a Stronghold of Free Thinking: Social, Ethical and Philosophical Dimensions of Buddhism (Neusttal, Germany, 2011) 183-202.

Zaccheti, Stefano, "Prajñāpāramitā Sūtras, « in Jonathan Silk, Oskar von Hinüber, and Vincent Eltschinger (eds.), Brill Encyclopedia of Buddhism 1 (Leiden, 2015) 171-209. 


\section{List of Figures:}

Figure 1: The young Buddha goes to school on a ram. Sahri Bahlol, Pakistan, second to third century CE. Peshawar Museum, access no. 3736. Photo: J. Cabezón.

Figure 2: The young Buddha (right) approaches his seated teacher in the classroom to show him his writing tablet. Gandhara, exact provenance unknown. Peshawar Museum, access no. 2737. Photo: J. Cabezón.

Figure 3: A monk of the Tantric College uses a text-stand (shokali) to read different strata of commentaries. Photo: J. Cabezón. 